Review

\title{
Development of Strategies for AOB and NOB Competition Supported by Mathematical Modeling in Terms of Successful Deammonification Implementation for Energy-Efficient WWTPs
}

\author{
Mehdi Sharif Shourjeh ${ }^{1}(\mathbb{D})$, Przemysław Kowal ${ }^{1}\left(\mathbb{D}, \mathrm{Xi} \mathrm{Lu}^{1,2}, \mathrm{Li} \mathrm{Xie}^{2}\right.$ and Jakub Drewnowski ${ }^{1, *(\mathbb{D})}$ \\ 1 Faculty of Civil and Environmental Engineering, Gdansk University of Technology, Narutowicza 11/12, \\ 80-233 Gdansk, Poland; mehdi.sharif.shourjeh@gmail.com (M.S.S.); przkowal@pg.edu.pl (P.K.); \\ xilu@pg.edu.pl or 1310446_lucy@tongji.edu.cn (X.L.) \\ 2 Institute of Environmental Science and Engineering, Tongi University, 1239 SiPing Road, \\ Shanghai 200092, China; sally.xieli@tongji.edu.cn \\ * Correspondence: jdrewnow@pg.edu.pl
}

check for updates

Citation: Sharif Shourjeh, M.; Kowal, P.; Lu, X.; Xie, L.; Drewnowski, J. Development of Strategies for AOB and NOB Competition Supported by Mathematical Modeling in Terms of Successful Deammonification Implementation for Energy-Efficient WWTPs. Processes 2021, 9, 562. https://doi.org/10.3390/pr9030562

Academic Editor: Kostas Matis

Received: 9 December 2020

Accepted: 15 March 2021

Published: 23 March 2021

Publisher's Note: MDPI stays neutral with regard to jurisdictional claims in published maps and institutional affiliations.

Copyright: (c) 2021 by the authors. Licensee MDPI, Basel, Switzerland. This article is an open access article distributed under the terms and conditions of the Creative Commons Attribution (CC BY) license (https:/ / creativecommons.org/licenses/by/ $4.0 /)$.
Abstract: Novel technologies such as partial nitritation (PN) and partial denitritation (PDN) could be combined with the anammox-based process in order to alleviate energy input. The former combination, also noted as deammonification, has been intensively studied in a frame of lab and full-scale wastewater treatment in order to optimize operational costs and process efficiency. For the deammonification process, key functional microbes include ammonia-oxidizing bacteria (AOB) and anaerobic ammonia oxidation bacteria (AnAOB), which coexisting and interact with heterotrophs and nitrite oxidizing bacteria (NOB). The aim of the presented review was to summarize current knowledge about deammonification process principles, related to microbial interactions responsible for the process maintenance under varying operational conditions. Particular attention was paid to the factors influencing the targeted selection of AOB/AnAOB over the NOB and application of the mathematical modeling as a powerful tool enabling accelerated process optimization and characterization. Another reviewed aspect was the potential energetic and resources savings connected with deammonification application in relation to the technologies based on the conventional nitrification/denitrification processes.

Keywords: deammonification; NOB suppression; microbial interaction; influencing factors; energy consumption; model-based analysis; kinetics

\section{Introduction}

The excess amount of the nutrients (in particular nitrogen and phosphorus), released to the environment from the point sources, such as wastewater treatment plants (WWTPs), is associated with eutrophication process acceleration and threatens aquatic life. While effective phosphorus removal from municipal wastewater could be ensured by coagulation, in terms of nitrogen removal, reasonable costs are obtained exclusively for the biological treatment. Thus, the principles of biological nitrogen removal (BNR) methods have stimulated interests worldwide [1]. A combination of the nitrification and denitrification is a conventional method for removing nitrogen from wastewater [2]. In the frame of the first process-nitrification ammonium is oxidized to nitrite by ammoniaoxidizing bacteria (AOB) (nitritation), and nitrite is subsequently converted to nitrate by nitrite-oxidizing-bacteria (NOB) (nitratation). After transition into anoxic conditions, under limited dissolved oxygen concentration, nitrite/nitrate is reduced to dinitrogen gas by heterotrophic denitrifies with organic compounds such as methanol, ethanol, acetate, or glucose, which serve as electron donors. On the one hand, systems based on conventional nitrification/denitrification $(\mathrm{N} / \mathrm{DN})$ enable to achieve high efficiencies of nitrogen 
removal, on the other hand, such efficiency comes at high operational costs (basically due to high oxygen demand to ensure full nitrification) and sufficient amount of easy bioavailable carbon source for denitrification has to be assured [3,4]. For example, N/DN processes consumes approximately $50 \%$ to $90 \%$ of electricity under pilot-scale conditions, which is $15-49 \%$ of the total operational costs $[5,6]$.

Currently, novel technologies of nitrogen removal have been intensively investigated in order to implement solutions for energy consumption savings and to lower carbon demand, which is based on partial nitritation (PN) and partial denitritation (PDN). These approaches could be combined with the anammox-based process as shown in Figure 1.

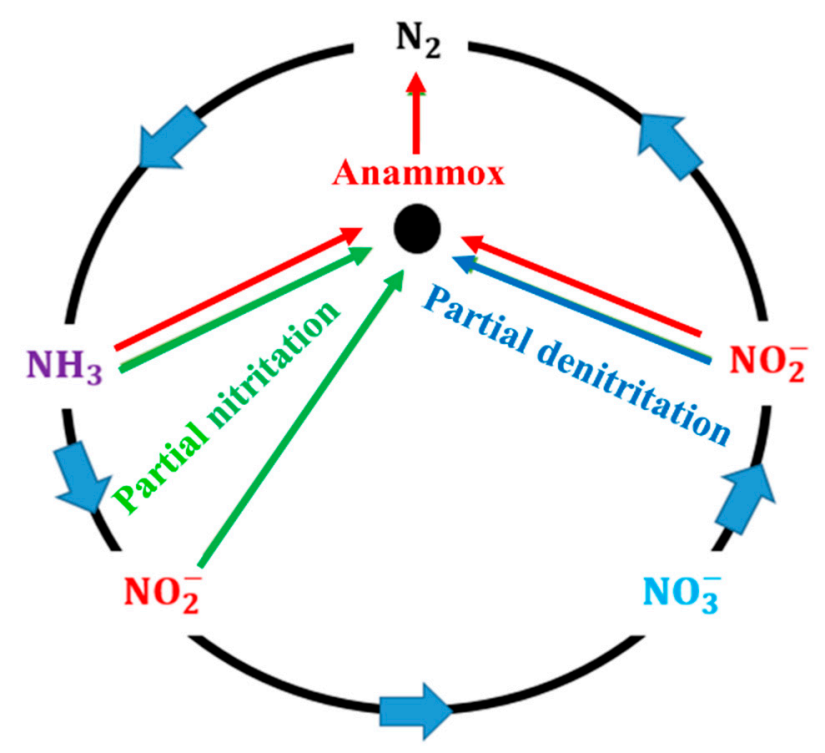

Figure 1. The schematic pathway of nitrogen transformation with implementation of technologies based on anammox process.

In particular, combination of the partial nitritation $(\mathrm{PN})$ and anaerobic ammonium oxidation (anammox, noted as A), so called deammonification, seems to be the most promising approach in that field $[7,8]$. During PN process, nearly $50 \%$ of ammonia is oxidized to nitrite and subsequently, the rest of ammonia with nitrite as an electron acceptor under anoxic conditions are converted together to nitrogen gas [1,4]. Several studies have proved that PN/A process can be successfully applied for lab and full-scale designs for side-stream lines in plants due to the elimination of carbon demand for denitrification and having costeffective benefits $[9,10]$. This pathway has diverted attention due to its appropriate benefits such as cost-saving approaches, reducing the oxygen demand, inhibiting the activities of denitrifies, eliminating carbon affinity for denitrification, improving sludge handling process in comparison with conventional methods to remove nitrogen from WWTPs [11]. Deammonification-based technologies have been applied for more than 100 full-scale plants around the world [1,12]. Strass WWTP has been known as a forerunner plant that has used the deammonification method successfully since 2004 [2,13,14].

Up to date, different systems based on the deammonification process implementation have been validated, including single reactor for high activity ammonium removal over nitrite (SHARON), completely autotrophic nitrogen removal over nitrite (CANON) which is an example of SNAP (single-stage nitrogen removal using anammox and partial nitritation), simultaneous partial nitrification, anammox, and denitrification (SNAD) (Figure 2) [15-18]. 
$\mathrm{T}>35^{\circ} \mathrm{C}$

Intermittent aeration

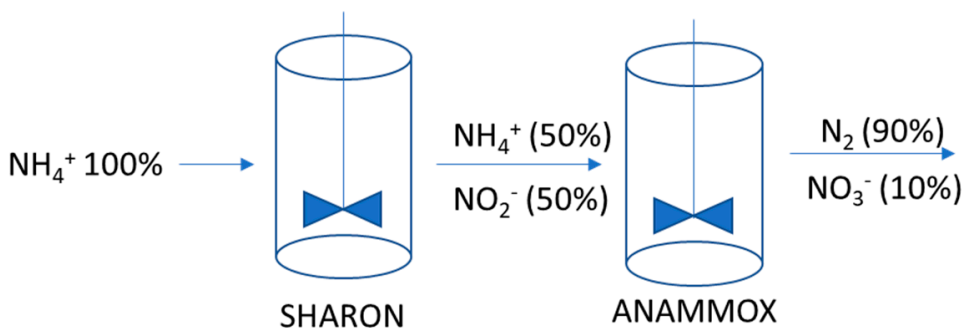

(a)

Low $\mathrm{C} / \mathrm{N}$

High conc. $\mathrm{NH}_{4}^{+}$

Intermittent aeration or continous aeration at $\mathrm{DO}<1.0 \mathrm{mg} / \mathrm{L}$

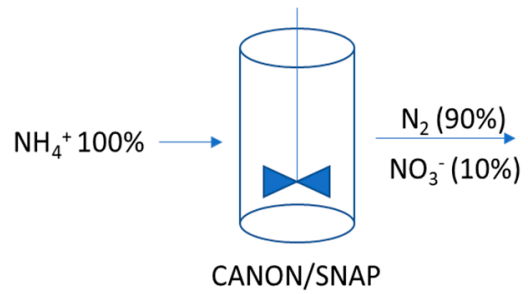

(b)

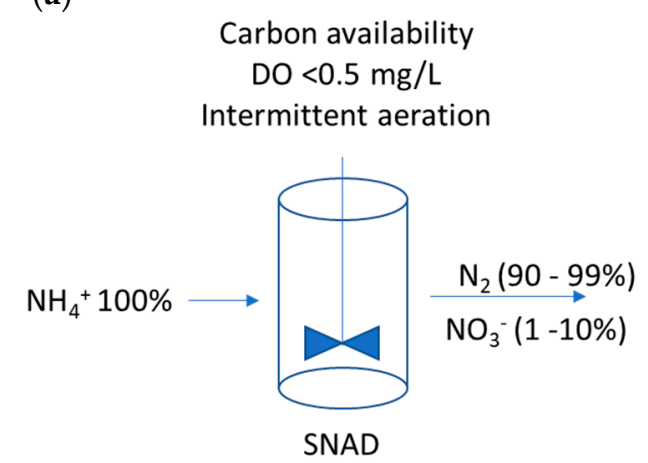

(c)

Figure 2. An overview of technologies based on the deammonification process: single reactor for high activity ammonium removal over nitrite (SHARON) (a) completely autotrophic nitrogen removal over nitrite CANON/ (single-stage nitrogen removal using anammox and partial nitritation SNAP (b) simultaneous partial nitrification, anammox, and denitrification SNAD (c).

The aim of the presented review was to summarize current knowledge about deammonification process principles, related to microbial interactions responsible for the process maintenance under varying operational conditions. Particular attention was paid to the factors influencing the targeted selection of $\mathrm{AOB} / \mathrm{AnAOB}$ over the $\mathrm{NOB}$ and application of the mathematical modeling as a powerful tool enabling accelerated process optimization and characterization. Another reviewed aspect was the potential energetic and resources savings connected with deammonification application in relation to the technologies based on the conventional nitrification/denitrification processes.

\section{Microorganisms Interaction through Shortcut Nitrification Systems}

Novel strategies (based on deammonification) are effectively developed in order to enrich biomass with $\mathrm{AOB}$ and $\mathrm{An} \mathrm{AOB}$ population or/and induce their activity, with parallel NOB suppression $[16,19]$. The interaction and competition between main internal bacteria including $\mathrm{AOB}, \mathrm{AnAOB}$, and $\mathrm{NOB}$ for common substrates are considered as a critical point for maintaining the stability of technologies based on the deammonification process (Table 1).

Table 1. Substrate and electron donors specified for the main microbial groups involved in nitrogen metabolism.

\begin{tabular}{ccc}
\hline Functional Group & Electron Donor & Electron Acceptor \\
\hline $\mathrm{AOB}$ & $\mathrm{NH}_{4}{ }^{+}$ & $\mathrm{O}_{2}$ \\
$\mathrm{NOB}$ & $\mathrm{NO}_{2}{ }^{-}$ & $\mathrm{O}_{2}$ \\
AnAOB & $\mathrm{NH}_{4}{ }^{+}$ & $\mathrm{NO}_{2}^{-}$ \\
\hline
\end{tabular}

The main dependencies are: competition between $\mathrm{AOB}$ and AnAOB for $\mathrm{NH}_{4}{ }^{+}-\mathrm{N}$ as an electron donor; $\mathrm{NOB}$ and $\mathrm{AnAOB}$ contest for nitrite as both, electron acceptor and 
donor; rivalry between $\mathrm{AOB}$ and $\mathrm{NOB}$ for oxygen substrate as an electron acceptor; $\mathrm{AOB}$, $\mathrm{NOB}$, and AnAOB competition for inorganic carbon (IC) [20,21].

Based on the processes kinetics performed by $\mathrm{AOB}$ and NOB, the minimal $\mathrm{AOB} / \mathrm{NOB}$ ratio of their abundance in the biomass, in order to maintain the stability of the deammonification process, is considered around 2:1 [22]. In addition, activity of the nitrifying autotrophic bacteria and dynamics of their population can be affected by applied reactor type, for instance, application of the moving bed biofilm reactor (MBBR) enables to maintain the stable deammonification process under low-temperature conditions [23].

\subsection{Ammonia Oxidizing Bacteria ( $A O B)$}

Currently, ammonia oxidizing bacteria responsible for the nitritation step are categorized into five genera: Nitrosomonas, Nitrosococcus, Nitrosospira, Nitrosolobus, and Nitrosorobrio. Several reports have suggested that representatives of the Nitrosomonas genus, which belongs to the $\beta$ subdivision of the Proteobacteria, constitutes commonly from 0.4 to $1.5 \%$ of the total biomass in the deammonification systems, at the same time, nitrifiers from the Nitrosomonas predominate AOB population at the share of $63-97.70 \%$ [21]. For instance, Huang et al., [23] who investigated the AOB community within one-stage PN/A process, have identified Nitrosomonas sp. HKU as the most abundant nitrifying bacterial group in the reactor [24].

The predominant role and the highest abundances of the Nitrosomonas genus in the frame of the AOB population in PN/A systems, is mainly attributed to their high substrate (as well under high ammonium concentrations) and oxygen affinities [4]. Yang et al. [24] observed that by decreasing ammonia concentration in the influent wastewater under mainstream conditions, the population of the AOB, validated by qPCR, decreased to $3.0 \times 10^{10}$ copies/ $\mathrm{L}$ in comprehension to $5.6 \times 10^{11}$ copies/L, during the experimental stage where elevated ammonium nitrogen loads were applied [25].

Previous studies have revealed that maximum specific growth rate $\left(\mu_{\mathrm{AOB}, \max }\right)$ of the $\mathrm{AOB}$, which is around $0.81-0.85 \mathrm{day}^{-1}$, was obtained for $\mathrm{pH}$ and temperatures at the ranges of $7.5-8$ and $30-35^{\circ} \mathrm{C}$, respectively [16].

While under strictly aerobic conditions, $\mathrm{AOB}$ growth is not limited by the electron acceptors availability, AOB are capable to maintain their growth under anoxic conditions relying on the remaining, limited DO concentration [25].

\subsection{Nitrite Oxidizing Bacteria (NOB)}

Nitrite oxidizing bacteria are catalyzers of the nitratation step during nitrification process. At the present, the NOB are classified within seven bacterial genera, Nitrospira, Nitrobacter, Nitrotoga, Nitrococcus, Nitrospina, and Nitrolancea [26,27]. NOB are known as Gram-negative bacteria with differential cell shapes such as rod, spiral, and spherical. Most of the NOBs genera are autotrophic and use $\mathrm{CO}_{2}$ as a carbon source for the biomass synthesis. Based on the characterization of the biomass composition obtained from the WWTPs with the modern molecular tools (for instance, high-throughput sequencing of the $16 \mathrm{~S}$ rRNA gene), representatives of the Nitrobacter and Nitrospira genera are recognized as the most abundant NOB in such ecosystems [28].

Yao and Peng. [21] have indicated that share of the NOB in the total bacterial communities of the biomass form the conventional WWTPs ranged from 1.0 to $5.0 \%$, within which 60.0-92.0\% were attributed to the representatives of the Nitrospira genus. NOB activity and growth rate depends on many operational factors, for instance, high level of SRT, low temperature, and concentration of ammonia, NOB growth in the system over AOB [29].

The predominance of the particular NOB genus, i.e., Nitrospira versus Nitrobacter is strongly dependent on the nitrite concentrations and availability [13]. Representatives of the Nitrobacter genus are adapted to higher nitrite concentrations in the contrary to the members of the Nitrospira, which prevail in the systems operated under moderate and relatively low nitrite loads/accumulation [7]. Moreover, limitation of the DO concentrations and extended SRTs are additional factors that promote Nitrospira growth over 
Nitrobacter [30]. On the other hand, since Nitrobacter has a lower affinity for oxygen than Nitrospira, hence under low DO concentrations but with nitrite availability, Nitrobacter would inhibit the activity of Nitrospira [31,32].

Additional aspect that should be taken into account, is a selection strategy specified for the particular microbial group. In line with the $\mathrm{r} / \mathrm{K}$ selection theory, organisms are classified into r-strategists or K-strategists based on their growth rate and affinity for the available substrates. In general, $\mathrm{r}$-strategists are defined by a fast growth rate at the high substrate availability and under low competition level with other microorganism, whereas $\mathrm{K}$-strategists grow faster when they are faced with limited substrate concentrations and are exposed to the strong competitiveness (Table 2) [2,33,34].

Particular genera of the AOB and NOB reflect variability in terms of $\mathrm{r} / \mathrm{K}$ strategies. For instance, in terms of affinity to the dissolved oxygen, Nitrosomonas europaea and Nitrobacter sp. due to low affinity are known as r-strategists while Nitrosospira and Nitrospira with a higher affinity are recognized as K-strategists [7,35].

Table 2. Predominating species in different biological processes.

\begin{tabular}{|c|c|c|c|c|c|c|}
\hline Reference & Main AOB & Main NOB & $\begin{array}{c}\text { Characteristic } \\
\text { Strategy }\end{array}$ & $\begin{array}{l}\text { Ammonium } \\
\text { Conversion } \\
\text { Efficiency\% }\end{array}$ & Biomass Type & Reactor \\
\hline [36] & Nitrosospira & Nitrospira & $\begin{array}{l}\text { k-strategists / k- } \\
\text { strategists }\end{array}$ & Completely & $\begin{array}{c}\text { Aerobic } \\
\text { granulation }\end{array}$ & SBR \\
\hline [37] & Nitrosomonas & Nitrobacter & $\begin{array}{l}\text { k-strategists /r- } \\
\text { strategists }\end{array}$ & 90 & $\begin{array}{c}\text { Activated } \\
\text { sludge }+ \\
\text { biofilm }\end{array}$ & $\begin{array}{c}\text { lab-scale } \\
\text { continuous- } \\
\text { flow } \\
\text { bioreactors }\end{array}$ \\
\hline [16] & $\begin{array}{c}\text { Nitrosomonas } \\
\text { europaea }\end{array}$ & Nitrospira & $\begin{array}{l}\text { r-strategists/k- } \\
\text { strategists }\end{array}$ & 99.4 & Biofilm & SBR \\
\hline [4] & $\begin{array}{l}\text { Nitrosomonas } \\
\text { sp. }\end{array}$ & - & r-strategists & 91.9 & $\begin{array}{l}\text { Granular } \\
\text { biomass }\end{array}$ & SBRs \\
\hline [38] & Nitrosospira sp. & - & k-strategists & 87.8 & $\begin{array}{c}\text { Cultivated } \\
\text { activated } \\
\text { sludge }\end{array}$ & MMBR \\
\hline [39] & Nitrosomonas & Nitrobacter & $\begin{array}{l}\text { r-strategists /r- } \\
\text { strategists }\end{array}$ & $>93$ & $\begin{array}{l}\text { Granular } \\
\text { biomass }\end{array}$ & SBR \\
\hline [40] & $\begin{array}{c}\text { Nitrosomonas } \\
\text { eutropha }\end{array}$ & $\begin{array}{l}\text { Nitrobacter } \\
\text { alkalicus }\end{array}$ & $\begin{array}{l}\text { k-strategists /r- } \\
\text { strategists }\end{array}$ & $\begin{array}{c}\text { From } 21 \% \text { to } \\
99 \% *\end{array}$ & $\begin{array}{l}\text { Activated } \\
\text { sludge }\end{array}$ & $\begin{array}{l}\text { continuously } \\
\text { stirred tank } \\
\text { reactor (CSTR) }\end{array}$ \\
\hline
\end{tabular}

* Efficiencies range for 6 six independent reactors differing with operating conditions.

\subsection{Anaerobic Ammonia Oxidizing Bacteria (AnAOB)}

Anammox bacteria are responsible for the oxidation of the ammonium in the presence of the nitrite, which serve as an electron acceptor under limited dissolved oxygen concentration. In the consequence nitrogen is transformed to the gaseous nitrogen, while about $10 \%$ from the initial sum of the ammonium and nitrite is remaining in the solution as a nitrate. Anammox are chemoautotrophic bacteria, which are a member of the original order Planctomycetales in frame of the Planctomycetes phylum [2] divided into 6 genera, Candidatus Kuenenia, Candidatus Brocadia, Candidatus Jettenia, Candidatus Anammoxoglobus, Candidatus Scalindua, and Candidatus Anammoximicrobium. AnAOB are commonly found in the various natural and artificial ecosystems such as, full and laboratory-scale bioreactors dedicated for wastewater treatment based on granular sludge and biofilm, as well in the freshwater or marine environment. In accordance to the literature, AnAOB reflect low growth rate at the moderate temperatures, for instance, their doubling time has been estimated around 17 days at the $20^{\circ} \mathrm{C}$ while, by increasing the temperature to $32-33{ }^{\circ} \mathrm{C}$, the doubling time increased up to 17 days with the maximum growth rate of 
0.0027 day $^{-1}[13,41]$. On the other hand, Gilbert et al. (2015) revealed that by gradual adaption, anammox activity was obtained at low temperatures (from 20 to $10^{\circ} \mathrm{C}$ ) [42].

Pereira et al. [43] revealed that the optimum ranges of $\mathrm{pH}$ and temperature for maintaining the stable growth rate for AnAOB are between 6.7-8.3 and $20-43^{\circ} \mathrm{C}$, respectively. Ye et al. [44] investigated the influence of starvation modes on AnAOB and subsequently nitrogen removal efficiency under SBR operation conditions, short-term starvations (1-4 days) lead to the increase in the tolerance and activity of $\mathrm{AnAOB}$, as well as the enhanced nitrogen removal efficiency to around $82.5 \%$.

\section{Factors Affecting Microorganisms Activity in Shortcut Nitrification Process}

Temperature, $\mathrm{DO}$, and $\mathrm{pH}$ are key parameters in wastewater treatment and their impact on the bacterial metabolism has been the subject of intensive research in recent years (Table 3). Such major operating factors can directly affect AOB, NOB, and AnAOB activity, as well indirectly influence other parameters e.g., free ammonia (FA) and free nitrous acid (FNA), indicating the importance of interaction among these factors to inhibit NOB activity through the shortcut nitrification process (Figure 3). Therefore, the following discussions focus briefly on the effects of the main operating factors on shortcut nitrification process efficiency and activity of the particular bacterial groups involved in nitrogen metabolism.

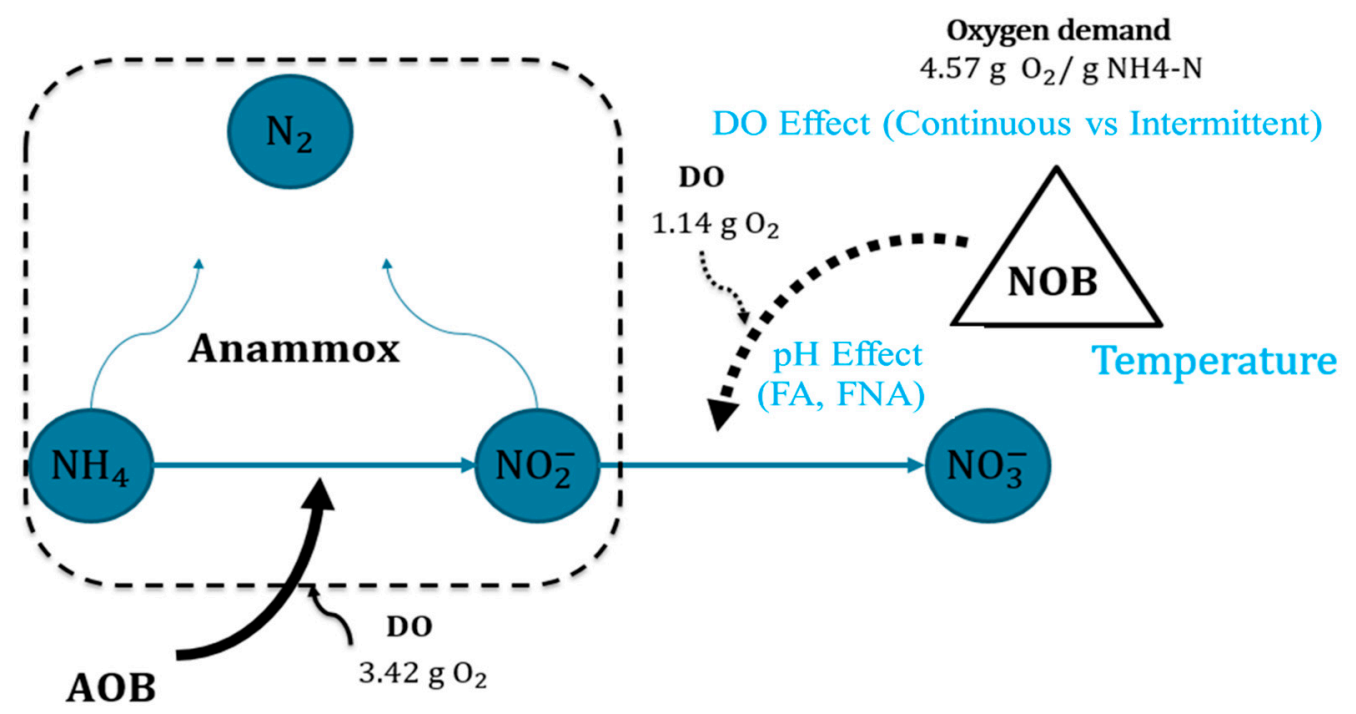

Figure 3. An overview of the role of influencing factor on nitrogen removal process. $3.42 \mathrm{~g} \mathrm{O}$ —oxygen demand for ammonium oxidation to nitrite; $1.14 \mathrm{~g} \mathrm{O}_{2}$ —oxygen demand for nitrite oxidation to nitrate; $4.57 \mathrm{~g} \mathrm{O}_{2}$ 一total oxygen demand for ammonium oxidation to nitrate [45].

\subsection{Temperature}

Based on the temperature dependency within nitrification process, obtaining optimal temperature can improve the shortcut nitrification process and maintain the beneficial ratio between $\mathrm{AOB}, \mathrm{NOB}$, and $\mathrm{AnAOB}$. The specific growth rate of the $\mathrm{AOB}$ during partial nitritation increases more than NOB under temperatures higher than $25^{\circ} \mathrm{C}$ [12]. By applying high temperatures and the low SRT, the inhibition of NOB activity, as well their washout from the system could be successfully achieved [46]. Furthermore, optimal temperatures for anammox-based technologies to achieve appropriate nitrogen removal efficiency have been proposed within the range $30-40{ }^{\circ} \mathrm{C}$ [47]. The highest activity of AnAOB was found at around $37^{\circ} \mathrm{C}$, whereas temperatures higher than $45^{\circ} \mathrm{C}$ led to the full process inhibition $[47,48]$. Along with the temperature decrease, AOB outcompete AnAOB, lead to the accumulation of nitrite, ammonium, and subsequently nitrate within anammox-based systems. Rodriguez-Sanchez et al. [49] investigated the impact of the low temperatures down to $15{ }^{\circ} \mathrm{C}$ for a single-stage partial nitritation/anammox granular 
sludge reactor, at the same time, $12.25 \%$ of the $\mathrm{AOB}$ and $9.50 \%$ of the AnAOB cooperated at an adequate level of mutual interaction for the stable nitrogen removal process [49].

Table 3. The interaction between major operational factors and alternative strategies.

\begin{tabular}{|c|c|c|c|c|c|c|}
\hline Reference & $\begin{array}{l}\text { Type of } \\
\text { Reactor }\end{array}$ & $\begin{array}{c}\mathrm{DO} \\
\left(\mathrm{mg} \mathrm{O} \mathrm{O}_{2} / \mathrm{L}\right)\end{array}$ & $\mathrm{pH}$ & $\begin{array}{c}\text { Temperature } \\
\left({ }^{\circ} \mathrm{C}\right)\end{array}$ & Efficiency (\%) & Strategy \\
\hline [50] & $\begin{array}{l}\text { Nitritation- } \\
\text { anammox-one } \\
\text { stage-MBBR- } \\
\text { Biofilm }\end{array}$ & $1.1-1.7$ & $7.2-8.2$ & $19-10$ & $\begin{array}{l}\text { N removal } \\
74-54\end{array}$ & $\begin{array}{l}\text { The process could } \\
\text { recover under low } \\
\text { temperature and stay } \\
\text { stable by increasing DO } \\
\text { concentration from } \\
1.1-1.7 \mathrm{mg} \mathrm{O}_{2} / \mathrm{L} \text {. }\end{array}$ \\
\hline [38] & $\begin{array}{c}\text { MBR-one } \\
\text { stage-activated } \\
\text { sludge }\end{array}$ & $\begin{array}{c}\text { Optimal } \\
0.8-0.9\end{array}$ & $7.25-7.35$ & $32-35$ & $\begin{array}{c}\text { Nitrite } \\
\text { accumulation in } \\
\text { average } 90.1\end{array}$ & $\begin{array}{l}\text { Low DO concentration } \\
\text { together with elevated } \\
\text { temperature and } \\
\text { FA-FNA control were } \\
\text { crucial factors for } \\
\text { PN process. }\end{array}$ \\
\hline [51] & IFAS & $0.4-1.5$ & $7.2-7.5$ & 15 or 17 & $\begin{array}{c}\text { N removal } \\
51\end{array}$ & $\begin{array}{c}\text { The attribution of } \\
\text { intermittent aeration } \\
\text { strategy with high DO } \\
\text { concentration more than } \\
1 \mathrm{mg} \mathrm{O}_{2} / \mathrm{L} \text { considered } \\
\text { for controlling } \\
\text { NOB activity. }\end{array}$ \\
\hline [52] & $\begin{array}{c}\text { One-stage } \\
\text { deammonifica- } \\
\text { tion } \\
\text { systems }\end{array}$ & $0.1-0.12$ & 7.6-8.3 & 32 & $\begin{array}{l}\text { Ammonium } \\
\text { removal in } \\
\text { average, } 72\end{array}$ & $\begin{array}{l}\text { The low range of DO was } \\
\text { recovered by applying } \\
\text { high temperature and FA } \\
\left(0.1-3 \mathrm{mg} \mathrm{O}_{2} / \mathrm{L}\right) \text { was } \\
\text { effective for } \\
\text { NOB inhibition. }\end{array}$ \\
\hline
\end{tabular}

Temperature reductions can influence the microbial community composition, thus affect shortcut nitrification efficiency. For instance, Lackner et al. [53] revealed that temperature decrease lower than $12{ }^{\circ} \mathrm{C}$ inhibited $\mathrm{AOB}$ and $\mathrm{AnAOB}$ activity, which resulted in drop of the ammonia conversion rate and nitrite accumulation for the both SBR and MBBR operated under lab scale.

The relation between temperature variations, the maximum specific growth rate of the microorganisms and activation energy could be described by (Arrhenius-type equation) (Equations (1) and (2)) in wastewater [54]. The theoretical range of temperature coefficients $(\theta)$ that shows the biomass activity has been reported between 1.02 to 1.10 for the high temperatures [55]. However, Guo et al. [56] showed a higher value for $\theta$ around 1.172 within lower temperatures $5-20{ }^{\circ} \mathrm{C}$ [56]. Furthermore, Sobotka et al., [20] found that $\theta$ within the batch test experiment was in agreement with the theoretical range, whereas by operating the long-term SBR test, temperature coefficients were 1.07 and 1.65 for $\left(15-30^{\circ} \mathrm{C}\right)$ and $\left(11-15^{\circ} \mathrm{C}\right)$ [21]. Activation energy factor $\left(E_{a}\right)$ (Equation (2)) showed same responses with $111.5 \mathrm{~kJ} \mathrm{~mol}^{-1}$ under lower temperatures $\left(5-20^{\circ} \mathrm{C}\right)$ and $42.0 \mathrm{~kJ} \mathrm{~mol}^{-1}$ for warmer conditions $\left(20-35^{\circ} \mathrm{C}\right)[13,56]$ :

$$
\begin{gathered}
r_{T}=r_{293} \times \theta^{(\mathrm{T}-293)}, \\
\mu_{\max , T}=\mu_{\max , 20{ }^{\circ} \mathrm{C}} \times \exp \left[-\frac{E_{a}}{\mathrm{RT}}\right], \\
\ln r_{T}=-\frac{E_{a}}{\mathrm{RT}}+\ln A
\end{gathered}
$$

where: 
$\mu_{\max , T}-$ Maximum specific growth rate $\left(\mathrm{d}^{-1}\right)$;

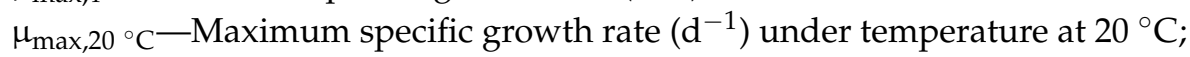

$E_{a}$-The activation energy $(\mathrm{KJ} / \mathrm{mol})$;

$\mathrm{R}-8.314(\mathrm{~J} / \mathrm{mol} \cdot \mathrm{K})$;

$r_{T}$-Reaction temperature at $\mathrm{T}$;

$\theta$-temperature coefficient;

$A$ - the frequency factor for the reaction;

$\mathrm{T}$-temperature in Kelvin.

Temperature fluctuations can influence the inhibitory impacts of free ammonia (FA) and free nitrous acid (FNA) on AOBs activities. Gabarró et al. [57] reported that FNA under both temperatures 25 and $35^{\circ} \mathrm{C}$ affected AOBs activity averagely $35 \%$, whereas FA only had an inhibitory impact nearly $22.1 \%$ at $35^{\circ} \mathrm{C}$ [57].

On the contrary, the specific growth rate of $\mathrm{AOB}$ had a sharp drop around 1.5 times when the controlled temperature decrease from 25 to $15^{\circ} \mathrm{C}$ was conducted [56]. Therefore, temperature changes influence the performance of the $\mathrm{PN}$ process due to the direct impact on the $\mathrm{AOB}$ and $\mathrm{NOB}$ population size. The growth rate of $\mathrm{NOB}$ within low temperatures between $10-20{ }^{\circ} \mathrm{C}$, is usually higher than $\mathrm{AOB}$, which leads to unfavorable AOB/NOB ration in the system and loss of the process stability [58].

However, partial nitritation strategies were implemented successfully within temperatures lower than $20{ }^{\circ} \mathrm{C}$. Isanta et al. [31] revealed that by simultaneous control of DO and ammonium concentrations ratio, partial nitritation process could be successfully maintained under lowered temperatures. This strategy was also implemented by Bian et al. [59], where careful adjustment of low DO concentrations, in a continuous moving bed biofilm reactor, ensured efficient system operation, even under the lowest from the applied temperature of $6{ }^{\circ} \mathrm{C}$. A stable autotrophic nitrogen removal process under temperature reduction from 20 to $10^{\circ} \mathrm{C}$ in lab-scale conditions with granular sludge was successfully achieved with the nitrogen removal efficiency changing between $85-75 \%$, when the DO concentration was increased up to $2.5 \mathrm{mg} \mathrm{O}_{2} / \mathrm{L}$ [59].

Another solution for the successful PN/A systems operation under low temperatures is application of the technologies based on the high concentration of the biomass maintenance in the bioreactors such as MBBRs. For instance, Gilbert et al. [60] obtained stable anammox activity under temperature lower down $10^{\circ} \mathrm{C}$, with parallel NOB suppression. In another study by Zekker et al. [61], gradual biomass adaptation in MBBR to the lowered temperatures as low as $9{ }^{\circ} \mathrm{C}$ ensured comparable nitrogen removal rates as in case of the measurements conducted at the temperature $20^{\circ} \mathrm{C}$.

\subsection{Dissolved Oxygen (DO) Set Point and Aeration Strategies}

Dissolved oxygen concentration is considered as the main factor affecting activity of the bacterial communities and successful operation of the shortcut in the nitrogen removal processes. The stability of the partial nitrification/nitritation relies on the inhibition of NOB activity, which depends on the dissolved oxygen concentration limitation during the reaction phase. Most researchers consider kinetic components that describe the oxygen dependency of bacteria, such as half-saturation constants specified for AOB and NOB in order to adjust the optimum DO set point in the system.

Cao et al. [62] observed a decreasing trend of the ammonium nitrogen concentration (conc. $\mathrm{NH}_{4}{ }^{+}-\mathrm{N}$ from 13.75 to $0.5 \mathrm{mg} / \mathrm{L}$ ) in the effluent from the in moving bed sequencing batch reactor (MBSBR), when an increasing DO concentration was applied to the system. At the same time, the nitrate accumulation increased from 0 to $9.8 \mathrm{mg} \mathrm{N} / \mathrm{L}$. In another study, when $\mathrm{DO}$ concentration was set at $3.5 \mathrm{mg} \mathrm{O}_{2} / \mathrm{L}$ conditions favoring for complete ammonia oxidation to nitrate were obtained [62].

Rodriguez-Sanchez et al. [38] revealed that value of the half-saturation constant for $\mathrm{AOB}$ and NOB were $0.2-0.4$ and $1.2-1.5 \mathrm{mg} / \mathrm{L}$, respectively, resulting that NOB activity is affected greater than $\mathrm{AOB}$ under low $\mathrm{DO}$ concentrations $\left(0.8-0.9 \mathrm{mg} \mathrm{O}_{2} / \mathrm{L}\right)$, leading to nitrite accumulation [38]. Li et al. [63] achieved total nitrogen removal efficiency nearly 
$81 \%$ under low DO concentration $0.6 \pm 0.1 \mathrm{mg} / \mathrm{L}$ within a nitritation-anammox process in an up flow membrane-aerated biofilm reactor (UMABR).

The implementation of the low DO $\left(0.5 \mathrm{mg} \mathrm{O}_{2} / \mathrm{L}\right)$, SRT (4 days), and sludge return ratio $(R=2.5)$ in the MBR configuration has been proposed as a promising solution to suppress NOB activity along with a high rate of nitrite accumulation over $80 \%$ [11].

\subsection{Intermittent Aeration Pattern}

An intermittent aeration strategy is a cost-effective alternative for inhibiting NOB and enriching AnAOB due to the accumulation of nitrite and consuming by AnAOB under different shortcut nitrification systems [64,65].

Contradictory findings have been suggested in the literature regarding the application of aeration strategies including intermittent and continuous aeration. For example, a continuous pattern was considered more preferable than the intermittent aeration method, since higher removal rate of nitrogen and ammonium was attained along with shorter aeration period $[1,66]$. Furthermore, Sobotka et al. (2015) found that the accumulation of nitrite increased toward more than $100 \mathrm{mg} \mathrm{N} / \mathrm{L}$ in the SBR under a continuous aeration pattern of which similar anammox activities were also observed based on the microbiological analysis [67].

On the other hand, the applicability and advantages of intermittent aeration strategy due to the inhibitory impact on NOB activities have gained strong interest worldwide. For instance, Y. Sun et al. (2017) reported that the intermittent strategy could promote the accumulation of nitrite, and after switching the continuous aeration method to the intermittent aeration system, NOB activities were dramatically limited, thus the stability of the reactor improved substantially [68]. Moreover, the nitrate build-up issue could be addressed under an intermittent aeration pattern (aeration $7 \mathrm{~min} /$ anoxic $21 \mathrm{~min}$ ), resulting in the inhibition of NOB activities and higher nitrogen removal rate within the PN/A process [69]. The possible combination of intermittent aeration strategy under low temperature conditions was proposed for maintaining $\mathrm{AOB}$ growth rate and inhibiting NOB activities using the gradient DO level during a different aeration rate [70].

The sustainability of partial nitrification increased under an intermittent pattern due to the enrichment of AOB microorganisms and inhibition of NOB activities [71]. However, in mainstream conditions, intermittent aeration can influence the activities of $\mathrm{AOB}$ and then the system efficiency [72,73]. NOB activities would be inhibited by using an intermittent aeration cycle when NOB are not able to translate quickly from the anoxic to aerobic phase [74]. Miao et al. (2016) reported that NOB activity reduced from 14.6 to $2.82 \mathrm{mg} \mathrm{N} /\left(\mathrm{h} \cdot \mathrm{g}_{\mathrm{VSS}}\right.$ ) and nitrogen removal rate reached $73 \mathrm{mg} \mathrm{N} /(\mathrm{L} \cdot \mathrm{d})$ under intermittent conditions [69]. The nitritation process was achieved through intermittent-fed SBRs under $20-26{ }^{\circ} \mathrm{C}$ for 300 days operation, near $93 \%$ of ammonium oxidized to nitrite [75].

Blum et al. (2018) demonstrated that $\mathrm{N}_{2} \mathrm{O}$ production decreased within partial nitritation in SBR when three major strategies were applied including, short-term cycles, low concentration of ammonium less than $100 \mathrm{mg} \mathrm{NH}_{4}{ }^{+}-\mathrm{N} / \mathrm{L}$, and high frequency in ON/OFF intermittent strategy [76].

The application of intermittent aeration with the ratio between the non-aerated and aerated period (1/3) showed to be particularly advantageous in a one-stage PN/A process including, the reduction in ammonium and nitrate concentration up to $17-20 \%$ within non-aerated phase, the maintenance of system stability even though the aeration time was decreased, the contribution of non-aerated phases in enriching AnAOB along with repressing NOB activity [77].

Bao et al. (2017) investigated the activity of $\mathrm{AOB}$ and NOB under high DO concentration, $\mathrm{AOB} / \mathrm{NOB}$ ratio changed from $3 / 1$ to $23 / 1$, indicating direct relation by $\mathrm{DO}$ changes which proves the inhibitory impact of high DO concentration on NOB populations, especially Nitrospira-like bacteria $[78,79]$. 


\section{4. $p H$ Direct Effect}

The $\mathrm{pH}$ dynamics through its effects on $\mathrm{NH}_{3}$ and $\mathrm{HNO}_{2}$ concentrations together with environmental variations can influence the community of $\mathrm{AOB}, \mathrm{NOB}$, and $\mathrm{AnAOB}$, affecting nitrogen removal efficiency along with nitrous oxide emission. Sudden changes in FA and FNA concentrations changed by $\mathrm{pH}$ value can have an inhibitory effect on NOB activity. Therefore, the relationship between $\mathrm{pH}$ and FA-FNA, and their potential interaction with other operational factors such as DO and temperature, can affect NOB population under nitrite pathway methods.

The adjustment of $\mathrm{pH}$ between 7.5 to 8.5 could achieve a desirable effect on partial nitrification processes and the accumulation of nitrite [28]. Under decreasing $\mathrm{pH}$ values from $8.0 \pm 0.1$ to $7.5 \pm 0.2$, ammonia oxidation activities and following the amount of nitrite accumulation decreased, while the activity of atrophic bacteria was repressed when $\mathrm{pH}$ was adjusted at 6.5 in this test [80], whereas the increasing $\mathrm{pH}$ from 7.5 to $8.3 \mathrm{can}$ enhance the rate of nitrite accumulation $1.68 \pm 1.51$ to $35.46 \pm 7.86 \%$ [81].

Feng et al. (2017) revealed that optimum $\mathrm{pH}$ for $\mathrm{AOB}$ and $\mathrm{NOB}$ activities are estimated 7.4 and 6-7.5 under temperature $30^{\circ} \mathrm{C}$ [13], whereas during another research study the fluctuation of $\mathrm{pH}$ between 7 and 8 would be a proper range to inhibit NOB under DO levels more than $0.5 \mathrm{mg} \mathrm{O}_{2} / \mathrm{L}$ [82]. Likewise, a higher removal rate of ammonium was observed under high $\mathrm{pH}$ around 8 compared to other biofilters under lower $\mathrm{pH}$ at 7.6 [83].

Organic carbon and $\mathrm{pH}$ can influence the nitrification efficiency, hence, the bioaugmentation process could enhance the ammonia removal efficiency up to 95\% [84]. Taylor et al. (2015) revealed $\mathrm{pH}$ as a major influencing factor on $\mathrm{N}_{2} \mathrm{O}$ accumulation, where $\mathrm{pH}=6$ could inhibit microorganisms activities [85]. The contribution of $\mathrm{pH}$ variations indicated that the highest concentration of $\mathrm{N}_{2} \mathrm{O}$ emissions occurred near to neutral $\mathrm{pH}$ within the partial nitrifying process $[86,87]$.

With an increasing level of $\mathrm{pH}$ from 6.5 to 8 applied to an intermittently-fed SBR reactor, results showed that a seven-fold increase occurred in $\mathrm{N}_{2} \mathrm{O}$ emissions and the $\Delta \mathrm{N}_{2} \mathrm{O} / \Delta \mathrm{NH}_{4}{ }^{+}$ratio [88]. Furthermore, Massara et al. [89] confirmed that the maximum extent of $\mathrm{N}_{2} \mathrm{O}$ production near $0.53 \pm 0.04\left(\mathrm{mg} \mathrm{N} \mathrm{N}_{2} \mathrm{O}-\mathrm{N} / \mathrm{h} \cdot \mathrm{g}_{\mathrm{vss}}\right)$ could happen in $\mathrm{pH}=8$, and also a linear relation was observed between the AOR and the $\mathrm{N}_{2} \mathrm{O}$ emissions within $\mathrm{pH}$ variation.

$\mathrm{pH}$ variations can affect the stability of the process due to the direct impact on FA and FNA concentrations. In previous research, it was reported that a reliable range of $\mathrm{pH}$ between 7-8 combined with low concertation of FA less than $2 \mathrm{mg} \mathrm{NH} / \mathrm{L}$ can achieve a stable nitrogen removal rate and protect the AnAOB population and activity under the MBBR system [83,90].

Hultman equation [91]:

$$
\mu_{\max }(\mathrm{pH})=\mu_{\max }(\mathrm{pH})_{o p t} \cdot \frac{1}{1+k\left(10^{\left|\mathrm{pH}_{\text {opt }}-\mathrm{pH}\right|}-1\right)} .
$$

Michaelis equation (Antoniou et al. [92], Angelidaki et al. [93]):

$$
\mu_{\max }(\mathrm{pH})=\mu_{\max }(\mathrm{pH})_{0.5} \cdot \frac{1+2 \times 10^{0.5 \cdot\left(p K_{h 1}-p K_{h 2}\right)}}{1+10^{\left(p K_{h 1}-\mathrm{pH}\right)}+10^{\left(\mathrm{pH}-p K_{h 2}\right)}} .
$$

\subsection{FA and FNA Inhibition Effect}

High concentrations of the ammonia in the influent or accumulation of the nitrite within the nitrification process, under proper conditions, lead to the occurrence of highly reactive and toxic free ammonia and free nitrous acid (FNA), respectively [94]. Especially, $\mathrm{pH}$ changes influence FA and FNA pool which interact to repress the growth rate of both AOB and NOB [95].

FA influences the activity of NOB more than that of AOB, while nitrite was accumulated due to the inhibitory effect of FA on Nitrobacter [96,97], for decreasing the activity 
of $\mathrm{AOB}, \mathrm{FA}$ concentrations in the range of $10-150 \mathrm{mg} \mathrm{NH}_{3} / \mathrm{L}$ are needed whereas for inhibiting NOB, the range was $0.1-1 \mathrm{mg} / \mathrm{L}$ [98]. Moreover, increasing the amount of FA from 0 to $16.82 \mathrm{mg} \mathrm{NH}-\mathrm{N} / \mathrm{L}$ indicated the reduced effect of $\mathrm{AOB}$ and NOB activities down to $15.9 \%$ and $29.2 \%$, respectively [99]. The nitrite was accumulated from $19.8-90 \%$ and nitritation successfully started up using the inhibitory effect of FA on NOB activities and real-time control strategy, under low temperatures $\left(13.0-17.6^{\circ} \mathrm{C}\right)$ [97]. Subsequently, the use of FA-based technologies could reduce the energy consumption rate from 0.27 to $0.14 \mathrm{kWh} / \mathrm{m}^{3}$ sewage treated [100].

Furthermore, it has been reported that increases in FNA could reduce the activity of NOBs more significantly than that of AOBs, leading to the nitrite accumulation $[7,101]$. Moreover, it was demonstrated that the dominance of the AOB population and $\mathrm{N}_{2} \mathrm{O}$ accumulation are quite sensitive to $\mathrm{pH}$ and FNA variations [86].

The AOB and NOB population could be affected by various concentrations of FNA, while the FNA concentration at the range of $0.42-1.72 \mathrm{mg} / \mathrm{L}, 50 \%$ of AOB was inhibited, NOB was completely inhibited, and the stabile PN/A process attained by applying an FNA concentration of $0.026-0.22 \mathrm{mg} \mathrm{NH}_{3} / \mathrm{L}$, indicating higher dependency of NOB to FNA changes than AOB [34,102,103].

An FNA-based strategy has also been considered as environmental friendly and economically beneficial methods due to producing methane and reducing the energy consumption for aeration, sludge handling, and sludge return line processes could also improve within applying FNA-based methods [104].

In the following equations [54], the relation of $\mathrm{pH}$ with FA and FNA concentrations $\left(\mathrm{mg} \mathrm{NH}_{3} / \mathrm{L}\right)$ is given:

$$
\begin{aligned}
\mathrm{FA} & =\frac{17}{14} \times \frac{\mathrm{TAN} \times 10^{\mathrm{pH}}}{\mathrm{e}^{\frac{6344}{273+\mathrm{T}}}+10^{\mathrm{pH}}}, \\
\mathrm{FNA} & =\frac{47}{14} \times \frac{\mathrm{TNN}}{\mathrm{e}^{-\frac{2300}{273+\mathrm{T}}} \times 10^{\mathrm{pH}}+1} .
\end{aligned}
$$

Haldane equation:

$$
\frac{\mu_{\max }(\mathrm{pH})}{\mu_{\max }(\mathrm{pH})_{o p t}}(\mathrm{FA}, \mathrm{FNA})=\frac{1}{\left(1+\frac{K_{m, \mathrm{FA}}}{\mathrm{FA}}+\frac{\mathrm{FA}}{K_{i, \mathrm{FA}}}\right)} \cdot \frac{1}{\left(1+\frac{K_{m, \mathrm{FNA}}}{\mathrm{FNA}}+\frac{\mathrm{FNA}}{K_{i, \mathrm{FNA}}}\right)}
$$

where TAN is total ammonium nitrogen and TNN is total nitrite nitrogen. $\mathrm{T}$ in ${ }^{\circ} \mathrm{C}$.

The pH changes based on (Equations (5) and (6)) can increase the concentration of FA within high $\mathrm{pH}$ and accumulate FNA during nitrification processes under low $\mathrm{pH}$, therefore, the adjustment of $\mathrm{pH}$ in order to control the inhibitory effect of FA and FNA on autotrophic bacteria behaviors can lead to optimize the nitrogen removal efficiency.

The bioaugmentation strategy is proposed as an effective way to reduce the SRT under nitrification process, as well the possible reduction of aeration time occurred when excess sludge brought the from sludge treatment system added to the wastewater system [105].

\section{Cost and Energy/Resources Reductions Comparing Conventional \& Deammonification}

It has been reported that the application of nitrite pathway methods coupled with anammox-based technologies can reduce operating and maintenance costs, including aeration, carbon demand, sludge disposal, and $\mathrm{N}_{2} \mathrm{O}$ emissions up to $85 \%$ on average $[106,107]$. Moreover, nitrogen removal costs through the nitrite pathway lead to a great reduction in oxygen demand (more than $50 \%$ on average), as well reduces the energy consumption to remove $1 \mathrm{~kg}$ of the nitrogen from $2.4 \mathrm{kWh} / \mathrm{N} \mathrm{kg}$ under conventional process to $1 \mathrm{kWh} / \mathrm{N}$ $\mathrm{kg}$ within PN/A technology [108,109]. Figure 4 compares the overall energy consumptions by the conventional and deammonification method, including oxygen, carbon, and $\mathrm{N}_{2} \mathrm{O}$ emission. The level of overall energy consumption within the conventional method was 
estimated at around $30 \mathrm{kWh} / \mathrm{PE} \cdot y e a r$, which is almost twice higher in comprehension to the $17 \mathrm{kWh} / \mathrm{PE} \cdot y e a r$ estimated for the deammonification system [110].

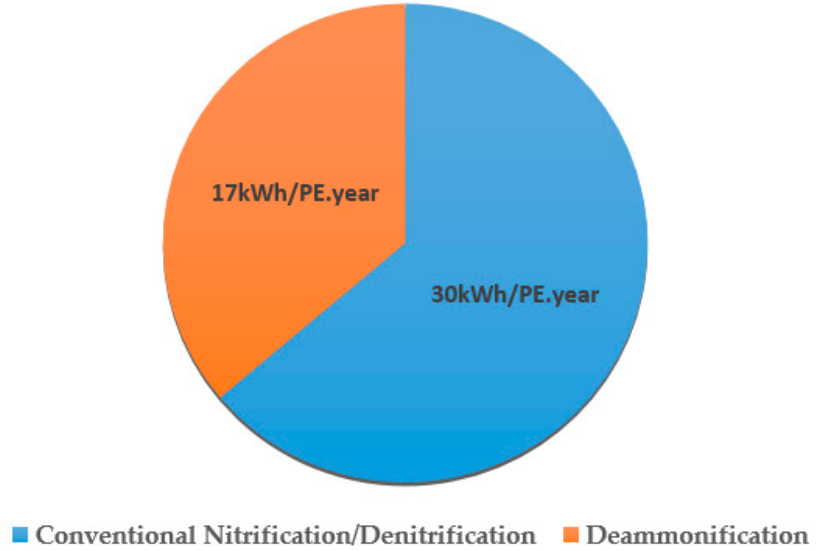

(a)

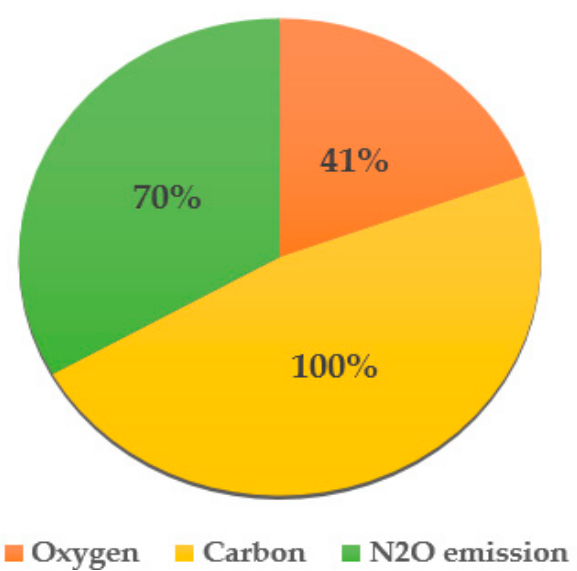

(b)

Figure 4. The role of deammonification vs. conventional nitrification/denitrification process on the decrease of overall amount of energy consumption (a) and oxygen consumption, nitrous oxide, and carbon from Wastewater Treatment Plant WWTP $(\mathbf{b})$ based on $[110,111]$.

\subsection{Energy Consumption in One-Stage Deammonification Systems}

In contrast, within one-stage reactors, partial nitrification and anammox processes occur simultaneously, hence the produced nitrite from the PN process is instantly converted to nitrogen gas by applying the anammox bacteria. Moreover, one-stage reactors have attracted more attention while nearly $88 \%$ of plants, due to cost-saving potentials and operational aspects, in comparison with two-stage configuration [1,112].

In addition, more than $50 \%$ of plants have made efforts to implement the deammonification process in WWTPs through the sequencing batch reactor (SBR) [66]. SBR would be operated with the use of granular anammox and suspended biomass to remove nutrients under intermittent or continues aeration within the lowest possible DO concentration $[1,66]$.

The popularity of the deammonification method is highly developed for the sidestream with high temperature and highly concentrated ammonium around $1 \mathrm{~g} \mathrm{~N} / \mathrm{L}$ in wastewater [12]. The implementation of this method in the side-stream line has beneficial results, since it decreases the competition between $\mathrm{AOB}$ and NOB bacteria under different affecting factors, including low DO concentrations, high temperatures, low SRTs, and free ammonia (FA) treatment $[9,113]$. Moreover, findings have demonstrated that the application of PN/A technology in the side-stream line is capable of removing total nitrogen from reject water, up to $88 \%$ with high ammonium removal efficiency near to $92 \%$ [4].

Therefore, the ideal configuration for the deammonification process in the side-stream would achieve advantages such as $60 \%$ and $85 \%$ reduction costs for aeration and sludge handling purposes, the use of accumulated nitrite as a substrate for AnAOB and the minimization of carbon demand approximately $100 \%$ for the denitrification process [106,114]. Moreover, within the deammonification process, a huge percentage of biodegradable organic matters convert to biogas due to the inhibition of denitrification bacteria activity, leading to expedite the procedure of nitrogen removal. [115].

To date, around $75 \%$ of PN/A reactors have been designed for side-stream line due to the energy-saving aspects while the feasibility of such methods has drawn special attention for the mainstream. The low concentration of ammonium (15-50 mg NH${ }_{4}^{+}-\mathrm{N} / \mathrm{L}$ ) and temperature $\left(10-15^{\circ} \mathrm{C}\right)$ in the mainstream as major factors can make challenges for process stability and the growth rate of microorganisms in comparison with side-stream $[9,53]$.

Furthermore, different operating factors can affect the performance of the PN/A process in the mainstream, for instance, high ratio of $\mathrm{COD} / \mathrm{N}$ in municipal wastewater 
leads to the inhibition of AnAOB activity; recently, Al-Hazmi et al. (2019) successfully operated the PN/A process under a mild ratio of $\mathrm{C} / \mathrm{N}(1-3)$, when the ratio increased from 1 to 3 , total nitrogen removal efficiency increased from $78.96 \%$ to $82.92 \%$ and $36.7 \%$ to $63.3 \%$ in the 1st and 2nd series and, respectively [116]. Moreover, other components contributing to the PN/A process are: lower alkalinity conditions can increase the requirements for adjusting $\mathrm{pH}$, the control of strong competition between AOB and NOB bacteria to use oxygen substrate, the accumulation of nitrite and the considerable start-up time $>1$ year due to the anammox-based technology to achieve desired nitrogen removal efficiency $[15,114]$.

In addition, mathematical modeling prepares proper conditions to better understand the microbial competition under various operational and environmental changes in order to optimize the process of deammonification [117]. For instance, the application of a dynamic model was investigated to simulate the behavior of anammox within different DO concentrations and evaluate the changes in the microbial community during competition and interaction with other bacteria [118].

\subsection{Energy Consumption in Two-Stage}

Two-stage configuration, as an alternative strategy, is comprised of two separated processes. Within stage A considered as a pre-treatment process under high rate activated sludge (HRAS) and chemically enhanced primary treatment (CEPT), the COD concentration is reduced to achieve the lowest range of organic compounds in the effluent. Then, during stage $\mathrm{B}$, the partial nitritation combined with the anammox process is implemented under low COD/N ratio (Figure 5). Due to the slow growth rate of the anammox bacteria, maintaining the balance between stage A-B and the controlling adequate retention time for the anammox process can influence the process stability [12]. One of the most important advantage of two-stage method is the reduction of competition between NOB and AnAOB over nitrite substrate compared with the one-stage method [31]. However, the implementation of the two-stage method based on the separated stages includes some drawbacks. For instance, higher maintenance costs, the challenge of mass balance between the output sludge for transferring to anaerobic digestion and returned sludge including high COD concentration in stage A, and as well as high temperature and SRT dependency of AnAOB for growing in the mainstream line which can cause challenges within the process [12].

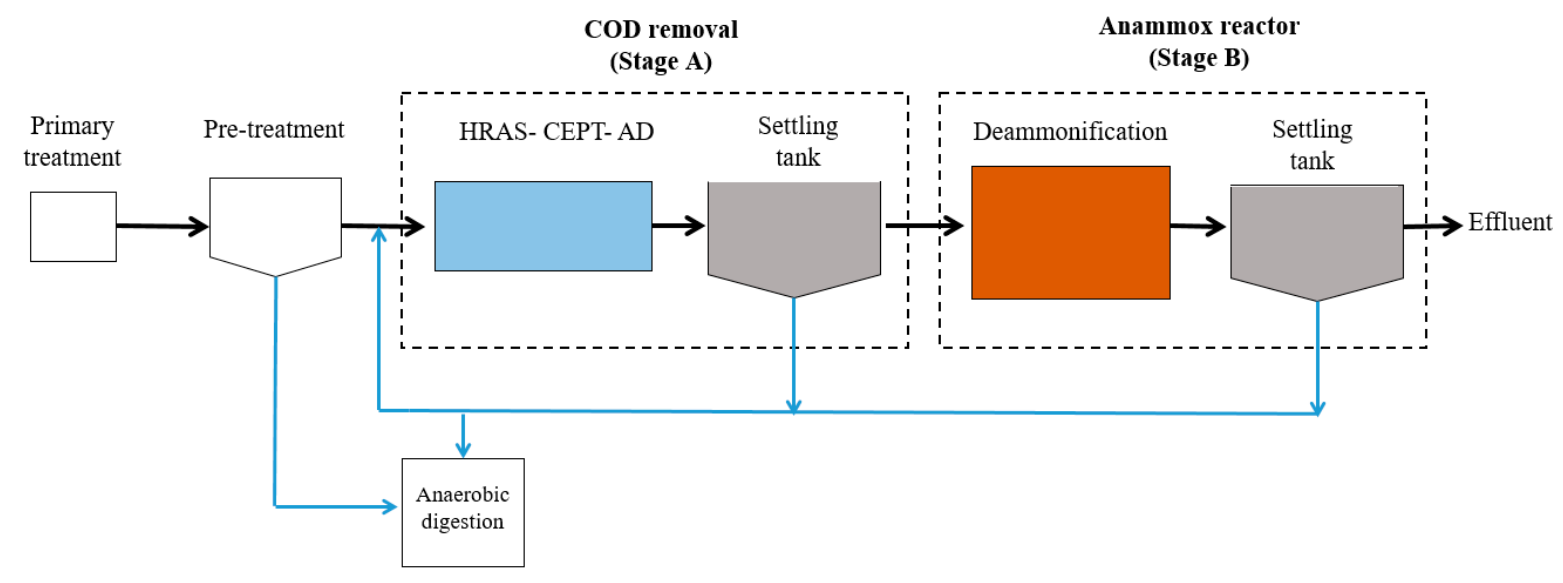

Figure 5. A two-stage configuration of the deammonification process based on [12].

For instance, a successful operation of two-stage reactor configuration was reported by Gu et al. [119], while within stage A, 58\% of influent COD was recovered to methane gas and was followed by around $75 \%$ reduction of sludge production, as well as $87 \%$ of total inorganic nitrogen (TIN) was simultaneously removed from the system, afterward during stage $B$, the nitritation-denitritation process, together with anammox strategy, were applied to remove nitrogen effectively. 


\section{Mathematical Modeling for Shortcut Nitrification Processes}

The mathematical models can be highly useful in order to simulate the behavior of kinetics within biological processes under different operating scenarios. These costeffectiveness models can significantly save operation costs and time combined with applying modifications in both the lab and pilot scale. Despite the advantages in operation aspects, new models can make a bridge between past, present, and future to find the optimum range of influencing factors participating in nitrogen removal processes for enhancing the process efficiency (Figure 6).

\subsection{Mathematical Kinetics Behavior of Microbial Community}

The kinetic of parameters can attribute to better understanding of the impact of operational factors on the activities of $\mathrm{AOB}, \mathrm{AnAOB}$, and $\mathrm{NOB}$ and comparing the effect of various factors applied to the system in order to optimize the nitritation pathway and inhibit NOB activities. The most common kinetic approaches to understand the growth rate of nitrifying bacteria are based on the Monod equation [120].

The principle kinetic parameters within the Monod equation are the maximum specific growth rate of $\mathrm{AOB}\left(\mu_{\max , \mathrm{AOB}}\right)$ and $\mathrm{NOB}\left(\mu_{\max , \mathrm{NOB}}\right)$. Diverse parameters can influence the growth rate of $\mathrm{AOB}$ and $\mathrm{NOB}$ in model calibration, for instance: the substrate concentrations, endogenous decay rate, temperature, $\mathrm{DO}$, and maximum specific growth rate [121]. Moreover, the growth rate of $\mathrm{AOB}$ is related to the concentration of ammonium in influent which could be followed by the NOB repression process. Oxygen is known as a common substrate for both $\mathrm{AOB}$ and $\mathrm{NOB}$, hence the affinity of $\mathrm{AOB}$ and $\mathrm{NOB}$ for oxygen are represented by half-saturation constants $\left(\mathrm{K}_{\mathrm{O}_{2}, \mathrm{AOB}}, \mathrm{K}_{\mathrm{O}_{2}, \mathrm{NOB}}\right)$ as sensitive parameters in the Monod equation [2].

In the following, an activated sludge model (ASM) based on Monod equations for the growth rate of $\mathrm{AOB}$ and $\mathrm{NOB}$ is presented:

$$
\begin{gathered}
\mu_{\mathrm{AOB}}=\mu_{\text {max }, \mathrm{AOB}} \times\left(\frac{\mathrm{S}_{\mathrm{NH}_{4}}}{\mathrm{~S}_{\mathrm{NH} 4}+\mathrm{K}_{\mathrm{NH} 4}}\right) \times\left(\frac{\mathrm{S}_{\mathrm{O} 2}}{\mathrm{~S}_{\mathrm{O} 2}+\mathrm{K}_{\mathrm{O} 2, \mathrm{AOB}}}\right)-\mathrm{b}_{\mathrm{AOB}}, \\
\mu_{\mathrm{NOB}}=\mu_{\text {max, } \mathrm{NOB}} \times\left(\frac{\mathrm{S}_{\mathrm{NO}_{2}^{-}}}{\mathrm{S}_{\mathrm{NO}_{2}^{-}}+\mathrm{K}_{\mathrm{NO}_{2}^{-}}}\right) \times\left(\frac{\mathrm{S}_{\mathrm{O} 2}}{\mathrm{~S}_{\mathrm{O} 2}+\mathrm{K}_{\mathrm{O} 2, \mathrm{NOB}}}\right)-\mathrm{b}_{\mathrm{NOB}}, \\
\mu_{\mathrm{AnAOB}}=\mu_{\max , \mathrm{AnAOB}} \times\left(\frac{\mathrm{S}_{\mathrm{NH} 4}}{\mathrm{~S}_{\mathrm{NH} 4}+\mathrm{K}_{\mathrm{NH} 4}}\right) \times\left(\frac{\mathrm{S}_{\mathrm{NO}_{2}^{-}}}{\mathrm{S}_{\mathrm{NO}_{2}^{-}}+\mathrm{K}_{\mathrm{NO}_{2}^{-}}}\right)-\mathrm{b}_{\mathrm{AnAOB}},
\end{gathered}
$$

where:

$\mu_{\max }$-maximum growth rate $\left(\mathrm{d}^{-1}\right)$;

$\mathrm{S}_{\mathrm{NH} 4}, \mathrm{~S}_{\mathrm{NO} 2}, \mathrm{~S}_{\mathrm{O}_{2}^{-}}$concentration of ammonia ( $\left.\mathrm{mg} \mathrm{N} / \mathrm{L}\right)$, nitrite (mg N/L), $\mathrm{DO}\left(\mathrm{mg} \mathrm{O}_{2} / \mathrm{L}\right)$;

$\mathrm{K}_{\mathrm{NH} 4}, \mathrm{~K}_{\mathrm{NO}_{2}^{-}}, \mathrm{K}_{\mathrm{O}_{2}^{-}}$ammonia, nitrite half-saturation constant (mg N/L), oxygen halfsaturation $(\mathrm{mg} / \mathrm{L}) \mathrm{b}$ is the decay rate $\left(\mathrm{d}^{-1}\right)$.

As well, as another application of the Monod equation for describing the inhibition approaches with different substrates have been shown [122]:

$$
\begin{gathered}
q=q_{\max } \times\left[\exp \left(-\frac{\mathrm{S}_{\mathrm{NH} 4}}{k_{i}}\right)-\exp \left(-\frac{\mathrm{S}_{\mathrm{NH} 4}}{k_{s}}\right)\right], \\
q=q_{\max } \times\left[\exp \left(-\frac{\mathrm{S}_{\mathrm{NO}_{2}^{-}}}{k_{i}}\right)-\exp \left(-\frac{\mathrm{S}_{\mathrm{NO}_{2}^{-}}}{k_{s}}\right)\right],
\end{gathered}
$$

where:

q-Specific growth rate per day;

$q_{\max }$-maximum specific growth rate per day for different bacteria;

$\mathrm{S}$ - substrate concentration $(\mathrm{mg} / \mathrm{L})$; 
$k_{S}$ and $k_{i}$ are half saturation constant and inhibition constant (mg N/L), respectively.

\subsection{The Application of Mathematical Models}

An activated sludge model no.1 (ASM1) describing simultaneous nitrification and denitrification was developed under low DO concentration less than $0.6 \mathrm{mg} \mathrm{O}_{2} / \mathrm{L}$, the proposed model displayed the sensitivity of $\mathrm{AOB}$ and $\mathrm{NOB}$ rather than $\mathrm{DO}$ variations [123].

An optimization framework was applied by the use of ASM3 to adjust the optimal aeration mode within an intermittent strategy under a partial nitrification pathway, followed by reducing energy consumption, as well as the linear constraints of the model facilitated its application for a quicker optimization process [124].

The application of an integrated mathematical model was investigated to observe $\mathrm{N}_{2} \mathrm{O}$ emissions by $\mathrm{AOB}$ and enhance nitrogen removal efficiency under controlled $\mathrm{DO}$ and nitrite concentrations [125]. In another paper, Guisasola et al. [126] utilized the ASM2d model to predict the behavior of $\mathrm{N}_{2} \mathrm{O}$ emissions within the control of $\mathrm{DO}$ variations for a municipal wastewater under anaerobic/anoxic/oxic configuration, the maximum extent of $\mathrm{N}_{2} \mathrm{O}$ emissions was estimated approximately $22 \%$ when DO and ammonium concentrations were controlled around $1.1 \mathrm{mg} \mathrm{O}_{2} / \mathrm{L}$ and 40, respectively [126].

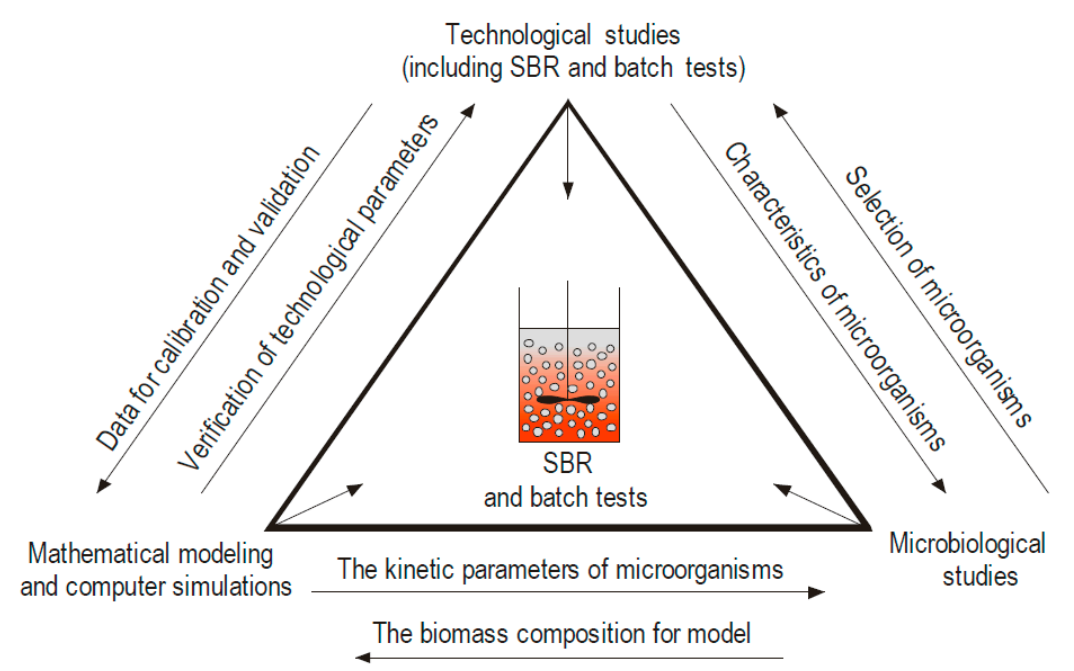

Figure 6. Interactions between technological, microbiological, mathematical modeling, and computer simulations approaches [127].

A recent modeling study predicted $\mathrm{pH}$ changes using modified nitritation and nitratation models, which developed to identify an optimal zone of influent ammonium, bicarbonate concentrations, and operating factors for achieving a high-efficient partial nitritation process [128].

A modified activated sludge model (ASM2d) was developed to simulate the behavior of major elements $\mathrm{COD}$, ammonium, and phosphate variations which were monitored according to the same results as the original ASM2d model; interestingly, the oxygen uptake rate (OUR) computed by modified model showed higher value, around 5.7\% compared with the basic model [129].

\subsection{Model-Based Simulations of NOB Suppression}

The one-dimensional multispecies biofilm model was used to simulate the performance of the granular sludge reactor, the proposed model was developed to determine the optimum range of operating parameters to attain a stable nitrogen removal process due to the inhibition of NOB activities constantly, based on the sensitivity analysis; $\mathrm{K}_{\mathrm{O}_{2}}$, $\mathrm{NOB} / \mathrm{K}_{\mathrm{O}_{2}}$, AOB ratio was recognized as main factors on $\mathrm{NOB}$ repression [130].

The competition among r-AOB, $\mathrm{K}-\mathrm{AOB}$, and $\mathrm{NOB}$ was investigated by the development of a mathematical model which was solved by MATLAB 7.5 software. The model 
outputs proved that autotrophic competitions are more dependent on SRT and $\mathrm{NH}_{4}{ }^{+}$ concentration within shortcut nitrification pathways [131].

In the same paper, Al-Omari et al. (2015) developed two strategies to repress NOB activity; the first one for a mainstream deammonification pilot was simulated based on the interaction among ammonium changes versus (nitrate + nitrite) (AVN), resulting in successful NOB out-selection and reduced additional carbon costs up to $60 \%$. In following, the second one was the combined control of SRT and AOB seeding (Bioaugmentation) in order to maximize the $\mathrm{AOB} / \mathrm{NOB}$ ratio for inhibiting $\mathrm{NOB}$ activity and recovering the AOB community [132].

An activated sludge No.1 (ASM1) was proposed to investigate the impact of different operating factors such as DO, SRT, and temperature on the nitrification process. The results generated by MATLAB/Simulink software showed that the DO was the most crucial factor, of which changes can extremely influence the process efficiency, as well as increasing DO was monitored as an effective strategy to improve the stability of the process within temperature variations [133].

Furthermore, the influence of DO limitation under intermittent strategy was evaluated by the development of an one-dimensional model. The results indicated that FA variations resulting by $\mathrm{pH}$ changes could primarily affect $\mathrm{NOB}$ activities, moreover, they revealed that in counter diffusion biofilm, $\mathrm{pH}$ adjustment is more crucial for suppressing NOB than DO changes [134].The growth rate of autotrophic bacteria within a partial nitrification process in the SBR system was described by the use of inhibition models and basic growth models based on Monod equation, the simulation outputs demonstrated that $\mathrm{AOB}$ retained and NOB washed out from the system under low DO concentrations in granular SBR as well as simultaneous inhibitory effect of FA and FNA varying sensitively by $\mathrm{pH}$ changes [135]. Examples of the mathematical models application have been summarized in Table 4 .

Table 4. The application of different mathematical models within nitrogen removal processes.

\begin{tabular}{|c|c|c|c|c|c|c|}
\hline Reference & Type of Reactor & Process & $\begin{array}{l}\text { Ammonium } \\
\text { Concentration } \\
\text { (mg N/L) }\end{array}$ & $\begin{array}{l}\text { Optimum DO } \\
\left(\mathrm{mg} \mathrm{O}_{2} / \mathrm{L}\right)\end{array}$ & Model Type & Strategy \\
\hline$[130]$ & Granular sludge & $\begin{array}{l}\text { single-stage } \\
\text { nitritation- } \\
\text { anammox }\end{array}$ & - & 1 & $\begin{array}{l}\text { One-dimensional } \\
\text { multispecies } \\
\text { biofilm model }\end{array}$ & $\begin{array}{l}\text { Applying different } \\
\text { DO and ammonium } \\
\text { concentration }\end{array}$ \\
\hline [136] & $\begin{array}{c}\text { complete } \\
\text { autotrophic } \\
\text { nitrogen removal } \\
\text { biofilm reactor }\end{array}$ & $\begin{array}{l}\text { nitritation and } \\
\text { anammox }\end{array}$ & $<50$ & 0.5 & $\begin{array}{l}\text { One-dimensional } \\
\text { biofilm model }\end{array}$ & $\begin{array}{c}\text { Biofilm } \\
\text { characteristic, DO } \\
\text { changes, } \\
\text { ammonium } \\
\text { concentrations } \\
\text { effects on } \mathrm{N}_{2} \mathrm{O}\end{array}$ \\
\hline [133] & $\begin{array}{l}\text { membrane } \\
\text { biological reactor }\end{array}$ & $\begin{array}{c}\text { anaerobic-anoxic } \\
\text {-aerobic }\end{array}$ & - & $1-3$ & ASM1 & $\begin{array}{l}\text { Effect of DO, SRT } \\
\text { and temperature }\end{array}$ \\
\hline$[134]$ & $\begin{array}{l}\text { membrane- } \\
\text { aerated biofilm } \\
\text { reactors (MABRs) }\end{array}$ & nitritation & 33 & & $\begin{array}{l}\text { A pH-explicit 1-D } \\
\text { multi-species } \\
\text { nitrifying biofilm } \\
\text { model (MSNBM) }\end{array}$ & $\begin{array}{c}\text { Intermittent } \\
\text { aeration, } \\
\text { considering DO } \\
\text { limitation, direct } \\
\text { and indirect pH } \\
\text { effects }\end{array}$ \\
\hline [137] & UCT-MBR & $\begin{array}{l}\text { nitrification and } \\
\text { denitrification }\end{array}$ & - & $<1.5$ & ASM2d & $\begin{array}{l}\text { The prediction of } \\
\mathrm{N}_{2} \mathrm{O} \text { based on } \\
\text { uncertanity for } \\
\text { optimizing plant } \\
\text { processes }\end{array}$ \\
\hline$[128]$ & SBR & partial nitritation & $19-84$ & 2 & ASM3 & $\begin{array}{l}\text { Predicting the } \\
\text { behavior of } \\
\text { operating and } \\
\text { influent conditions } \\
\text { for partial } \\
\text { nitrification process }\end{array}$ \\
\hline
\end{tabular}




\section{Perspectives}

Several studies have shown that shortcut nitrification methods coupled with anammox processes have gained increasing attention due to being cost-effective. The implementation of such methods in the side-stream line for high-strength wastewater has beneficial results, since it decreases the competition between $\mathrm{AOB}$ and $\mathrm{NOB}$ under low $\mathrm{DO}$ concentration, high temperature, low solids retention time (SRT), and free ammonia (FA) treatment. However, the application of such technologies has become state of the art for mainstream conditions under lower ammonium concentrations and seasonal temperatures. To date, the deammonification process under both lab-scale and full-scale conditions have become popular due to an increase in reducing the oxygen demand followed by cost-saving achievements, the elimination of carbon demands for denitrification process, and the improvement of sludge handling aspects [13]. However, the performance of shortcut nitrification strategies including the deammonification process depends on the enrichment of $\mathrm{AOB}$ and $\mathrm{AnAOB}$ population and the inhibition of $\mathrm{NOB}$ activities. Recent studies have revealed a variety of perspectives to improve the performance of shortcut nitrification methods including:

1. The changes in reactor operation and configuration, for instance, the elimination of carbon within a partial nitrification process with the application of two-stage configuration [12].

2. The recognition of functional microbial communities and their features for considering the appropriate strategies to outcompete NOB species against the AOB community.

3. The identification of main operating factors affecting AOB and NOB competition within different phases in order to apply the optimum range of such parameters for maintaining the stability of the process. The main bottlenecks in this step are related to the differences of specific growth rates of bacteria under various operating conditions. For instance, the high DO concentrations can enhance the activity of both $\mathrm{AOB}$ and $\mathrm{NOB}$, whereas due to the slower growth rate of $\mathrm{AOB}$ than NOB, the complete nitrification process could occur by $\mathrm{AOB}$ repression and nitrate accumulation. Moreover, AnAOB are sensitive to aerobic conditions while their activities will be inhibited under aerated processes. Therefore, the optimal operational conditions should be further considered for enriching AOB and AnAOB over NOB based on their dominating species ( $\mathrm{K}$ and R-strategists).

4. Alternative and supplemental strategies have gained attention due to maintaining the stability of the nitritation process, but these strategies need to be further studied to suppress NOB activities based on the mutual interaction between different operating parameters. Such possible strategies might be: (1) intermittent aeration operation as an effective method to successfully inhibit NOB activities under optimal aeration frequency under aerobic/anoxic conditions; (2) gradual decrease of temperature coupled with applying biomass to the system as an alternative to perform shortcut nitrification methods even under lower temperatures [61]; (3) bioaugmentation strategy may be useful to increase the nitrogen removal efficiency, the enrichment of nitrifier activities, and quicker start-up even under lower temperatures and DO concentrations [105,138]; (4) FA and FNA can inhibit AOB and NOB activities, as well as this inhibitory impact of FA and FNA on NOB is much more than AOB, so this method should be further investigated to identify the optimum range for these variables based on $\mathrm{pH}$ changes [7]; (5) the use of supplemental process to make the nitritation process much more efficient and decrease the consequences of carbon sources on the growth rate of bacteria under mainstream conditions. For instance, the use of carbon substrate for developing novel technologies based on simultaneous partial nitrification, anammox, and denitrification (SNAD) [139]; (6) To date, extensive efforts have been done for evaluating the interesting possibility of applying different types of biomasses including suspended sludge, biofilm, and granules within the nitrogen removal processes. Furthermore, the combination of different biomasses such suspended sludge (the enrichment of AOB-NOB activities) and biofilm or granules (the improvement of anammox activity) 
into reactors are gaining increasing interest for nitrite pathway methods which can enhance nitrogen removal efficiency (Figure 7, Table 5). Laureni et al. (2019) reported that the combination of biofilm with floc biomasses can have a significant effect on AnAOB and AOB-NOB activities, which was successfully followed by inhibiting NOB activity under decreasing DO concentration from 1.2 to $0.17 \mathrm{mg} \mathrm{O}_{2} / \mathrm{L}$ (Figure 8) [140].

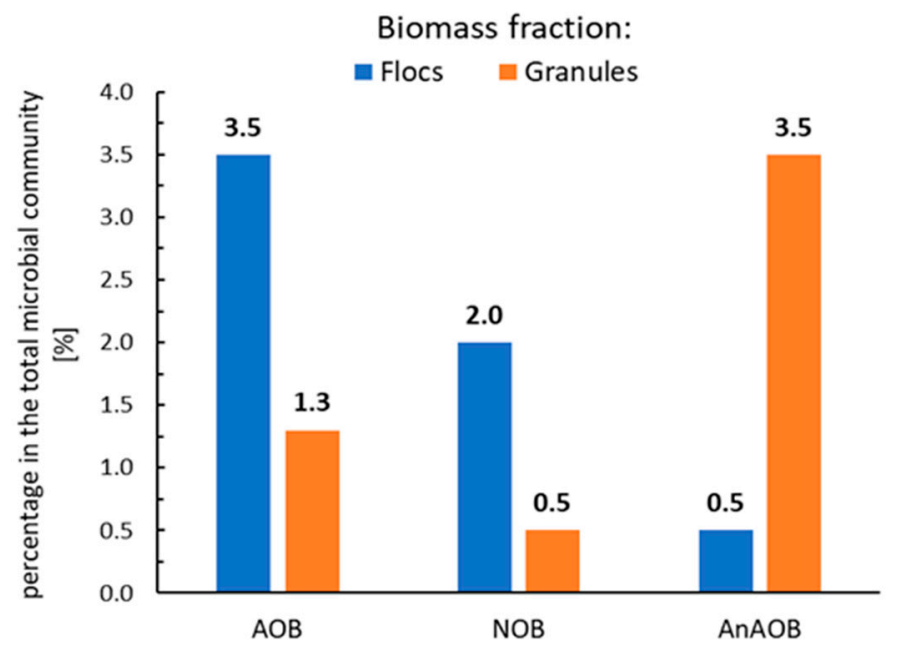

Figure 7. The abundance of different bacteria under the presence of flocs and granules based on [141].

Table 5. The introduction of different biomasses retention strategies in literature.

\begin{tabular}{|c|c|c|c|c|c|c|}
\hline Reference & $\begin{array}{l}\text { Type of } \\
\text { Reactor }\end{array}$ & Type of Biomass & AOB/NOB & $\begin{array}{c}\text { DO } \\
\left(\mathrm{mg} \mathrm{O}_{2} / \mathrm{L}\right)\end{array}$ & Temperature $\left({ }^{\circ} \mathrm{C}\right)$ & $\begin{array}{l}\text { Removal } \\
\text { Efficiency }\end{array}$ \\
\hline [53] & PN-A & Biofilm & $\begin{array}{c}(\mathrm{AOB} / \mathrm{NOB})>1 \\
\text { Within }>17^{\circ} \mathrm{C}\end{array}$ & $0.44 \pm 0.15$ & $10-20$ & - \\
\hline [31] & $\begin{array}{c}\text { partial } \\
\text { nitritation }\end{array}$ & Granules & $72 \pm 8$ to $81 / 19$ to 1 & $1-5$ & 12.5 & - \\
\hline [139] & $\begin{array}{c}\text { partial } \\
\text { nitrification } \\
\text { granules }\end{array}$ & Granules & $0.4 /-$ & $2.5-7$ & $25 \pm 1$ & $7.8-8.2 \%$ \\
\hline [140] & $\begin{array}{c}\text { partial } \\
\text { nitritation }\end{array}$ & Granules & $\begin{array}{l}41 \text { and } 65 / 1.4 \\
\text { And } \\
92 \pm 4 / 1 \pm 1\end{array}$ & $0.5-2.5$ & 10 & - \\
\hline [141] & $\mathrm{PN}$ & $\begin{array}{c}\text { Biofilm (R2) + } \\
\text { Activated } \\
\text { sludge(R1) }\end{array}$ & $\begin{array}{l}\mathrm{R} 1(62.5 / 6.5-1.8) \\
\mathrm{R} 2(47.3 / 0.8-2.6)\end{array}$ & 0.3 & $14-16$ & $\mathrm{ARE}=100 \%$ \\
\hline [142] & SND & Biofilm & $\begin{aligned} 0.082 \text { in } \mathrm{DO} & =4.5 / 0.766 \text { in } \\
\mathrm{DO} & =2.5\end{aligned}$ & $1.5-5.5$ & $30 \pm 2$ & $83.73 \%$ \\
\hline [143] & SBR & Activated sludge & $3.93 / 1.09$ & $0.1-0.6$ & $26.6-16.6$ & $\begin{array}{c}\text { Average of } \\
\text { ammonium } \\
\text { removal, } 93 \%\end{array}$ \\
\hline [144] & $\mathrm{PN} / \mathrm{A}$ & micro-granule & $10.5 / 8.2$ & $0.1-0.2$ & 25 & $72 \pm 10 \%$ \\
\hline
\end{tabular}




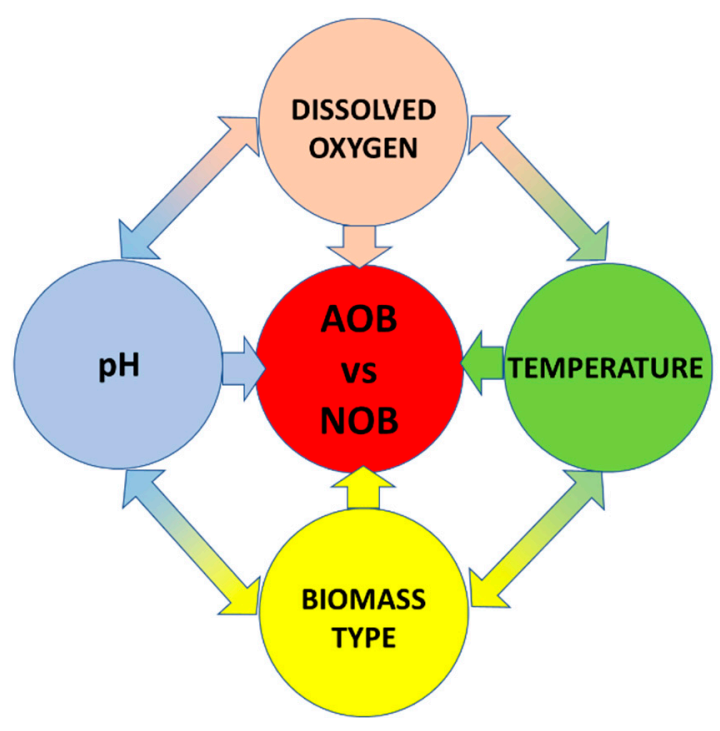

Figure 8. Interactions between different operational factors and ammonium oxidizing bacteria (AOB) - nitrite oxidizing bacteria (NOB) competition.

Model-based approaches could be useful for simulating the influence of operational parameters on nitrogen removal efficiency due to enhancement AOB and AnAOB activity, as well inhibiting the activity of NOBs for different configurations. Furthermore, the application of mathematical models would be further considered as a fast and fairly accurate optimization framework in order to calibrate models for prediction purposes.

\section{Conclusions}

The main challenge for implementing a shortcut in nitrogen removal processes from the wastewater is related to the strong competition between functional microbial groups responsible for nitrogen metabolism. In particular, activity of the NOB negatively affects the stability of the nitrogen removal processes which is the result of high operational and maintenance costs. Several studies have focused on the single impact of influencing factors on NOB activity (e.g., limited DO and low temperature conditions, intermittent aeration strategies, FA-FNA approaches); however, the simultaneous effect of various strategies is still represents a significant amount of missing knowledge under lab-scale and large-scale conditions. Therefore, the development of combined strategies for identifying the optimum operational conditions along with the use of a relevant type of biomass can kinetically inhibit NOB activity and enrich AOB activity, leading to simplify the nitrification process and decrease the additional aeration consumption and carbon source. Furthermore, modelbased methods can be employed to better understand the kinetic behavior of different bacteria and investigate different inhibitory strategies for repressing NOB activity and subsequently, making the deammonification process easier to maintain, more cost-effective, and environmentally sustainable.

Author Contributions: Conceptualization, J.D. and P.K.; resources, M.S.S.; writing—original draft preparation, M.S.S. and X.L. and J.D.; writing-review and editing, P.K. and X.L. and L.X.; visualization, P.K.; supervision, J.D.; project administration, JD.;. All authors have read and agreed to the published version of the manuscript.

Funding: This work was financially supported by the National Science Centre as a result of the research project no. 2017/26/D/ST8/00967, by Ministry of Science and Higher Education in Poland, within the statutory research of particular scientific units and by Shanghai international collaboration project (17230741000).

Institutional Review Board Statement: Not applicable.

Informed Consent Statement: Not applicable. 


\section{Data Availability Statement: Not applicable.}

Conflicts of Interest: The authors declare no conflict of interest.

\section{References}

1. Lackner, S.; Gilbert, E.M.; Vlaeminck, S.E.; Joss, A.; Horn, H.; van Loosdrecht, M.C. Full-scale partial nitritation/anammox experiences-An application survey. Water Res. 2014, 55, 292-303. [CrossRef] [PubMed]

2. Ma, B.; Wang, S.; Cao, S.; Miao, Y.; Jia, F.; Du, R.; Peng, Y. Biological nitrogen removal from sewage via anammox: Recent advances. Bioresour. Technol. 2016, 200, 981-990. [CrossRef] [PubMed]

3. Fux, C.; Siegrist, H. Nitrogen removal from sludge digester liquids by nitrification/denitrification or partial nitritation/anammox: Environmental and economical considerations. Water Sci. Technol. 2004, 50, 19-26. [CrossRef] [PubMed]

4. Dosta, J.; Vila, J.; Sancho, I.; Basset, N.; Grifoll, M.; Mata-Álvarez, J. Two-step partial nitritation/Anammox process in granulation reactors: Start-up operation and microbial characterization. J. Environ. Manag. 2015, 164, 196-205. [CrossRef]

5. Drewnowski, J.; Remiszewska-Skwarek, A.; Duda, S.; Łagód, G. Aeration process in bioreactors as the main en-ergy consumer in a wastewater treatment plant. Review of solutions and methods of process optimization. Processes 2019, 7, 311. [CrossRef]

6. Masłoń, A.; Czarnota, J.; Szaja, A.; Szulżyk-Cieplak, J.; Łagód, G. The Enhancement of Energy Efficiency in a Wastewater Treatment Plant through Sustainable Biogas Use: Case Study from Poland. Energies 2020, 13, 6056. [CrossRef]

7. Wang, D.; Wang, Q.; Laloo, A.E.; Xu, Y.; Bond, P.L.; Yuan, Z. Achieving Stable Nitritation for Mainstream Deammonification by Combining Free Nitrous Acid-Based Sludge Treatment and Oxygen Limitation. Sci. Rep. 2016, 6, 25547. [CrossRef]

8. Wang, X.; Yan, Y.; Gao, D. The threshold of influent ammonium concentration for nitrate over-accumulation in a one-stage deammonification system with granular sludge without aeration. Sci. Total Environ. 2018, 634, 843-852. [CrossRef]

9. Han, M.; De Clippeleir, H.; Al-Omari, A.; Wett, B.; Vlaeminck, S.E.; Bott, C.; Murthy, S. Impact of carbon to nitrogen ratio and aeration regime on mainstream deammonification. Water Sci. Technol. 2016, 74, 375-384. [CrossRef]

10. Malovanyy, A.; Yang, J.; Trela, J.; Plaza, E. Combination of upflow anaerobic sludge blanket (UASB) reactor and partial nitritation/anammox moving bed biofilm reactor (MBBR) for municipal wastewater treatment. Bioresour. Technol. 2015, 180, 144153. [CrossRef]

11. Jardin, N.; Hennerkes, J. Full-scale experience with the deammonification process to treat high strength sludge water-A case study. Water Sci. Technol. 2012, 65, 447-455. [CrossRef] [PubMed]

12. Xu, G.; Zhou, Y.; Yang, Q.; Lee, Z.M.-P.; Guanging, X.; Lay, W.; Cao, Y.; Liu, Y. The challenges of mainstream deammonification process for municipal used water treatment. Appl. Microbiol. Biotechnol. 2015, 99, 2485-2490. [CrossRef]

13. Feng, Y.; Lu, X.; Al-Hazmi, H.; Makinia, J. An overview of the strategies for the deammonification process start-up and recovery after accidental operational failures. Rev. Environ. Sci. Bio/Technol. 2017, 16, 541-568. [CrossRef]

14. Wett, B.; Murthy, S.; Tak'cs, I.; Hell, M.; Bowden, G.; Deur, A.; O'Shaughnessy, M. Key Parameters for Control of DEMON Deammonification Process. Configurations 2007, 1, 1-16.

15. Gonzalez-Martinez, A.; Morillo, J.; Garcia-Ruiz, M.; Gonzalez-Lopez, J.; Osorio, F.; Martinez-Toledo, M.; Van Loosdrecht, M. Archaeal populations in full-scale autotrophic nitrogen removal bioreactors operated with different technologies: CANON, DEMON and partial nitritation/anammox. Chem. Eng. J. 2015, 277, 194-201. [CrossRef]

16. Zhang, J.; Zhou, J.; Han, Y.; Zhang, X. Start-up and bacterial communities of single-stage nitrogen removal using anammox and partial nitritation (SNAP) for treatment of high strength ammonia wastewater. Bioresour. Technol. 2014, 169, 652-657. [CrossRef]

17. Shalini, S.S.; Joseph, K. Nitrogen management in landfill leachate: Application of SHARON, ANAMMOX and combined SHARON-ANAMMOX process. Waste Manag. 2012, 32, 2385-2400. [CrossRef]

18. Sun, X.; Zhang, H.; Cheng, Z.; Wang, S. Effect of low aeration rate on simultaneous nitrification and denitrification in an intermittent aeration aged refuse bioreactor treating leachate. Waste Manag. 2017, 63, 410-416. [CrossRef]

19. Agrawal, S.; Karst, S.M.; Gilbert, E.M.; Horn, H.; Nielsen, P.H.; Lackner, S. The role of inoculum and reactor configuration for microbial community composition and dynamics in mainstream partial nitritation anammox reactors. MicrobiologyOpen 2017, 6, e00456. [CrossRef]

20. Ma, Y.; Sundar, S.; Park, H.; Chandran, K. The effect of inorganic carbon on microbial interactions in a biofilm nitritation-anammox process. Water Res. 2015, 70, 246-254. [CrossRef]

21. Sobotka, D.; Czerwionka, K.; Makinia, J. Influence of temperature on the activity of anammox granular biomass. Water Sci. Technol. 2016, 73, 2518-2525. [CrossRef]

22. Yao, Q.; Peng, D.-C. Nitrite oxidizing bacteria (NOB) dominating in nitrifying community in full-scale biological nutrient removal wastewater treatment plants. AMB Express 2017, 7, 1-11. [CrossRef]

23. Huang, X.; Sun, K.; Wei, Q.; Urata, K.; Yamashita, Y.; Hong, N.; Hama, T.; Kawagoshi, Y. One-stage partial nitritation and anammox in membrane bioreactor. Environ. Sci. Pollut. Res. 2016, 23, 11149-11162. [CrossRef]

24. Yang, Y.; Zhang, L.; Cheng, J.; Zhang, S.; Li, X.; Peng, Y. Microbial community evolution in partial nitritation/anammox process: From sidestream to mainstream. Bioresour. Technol. 2018, 251, 327-333. [CrossRef]

25. Spieck, E.; Keuter, S.; Wenzel, T.; Bock, E.; Ludwig, W. Characterization of a new marine nitrite oxidizing bacterium, Nitrospina watsonii sp. nov., a member of the newly proposed phylum "Nitrospinae". Syst. Appl. Microbiol. 2014, 37, 170-176. [CrossRef]

26. Watson, S.W.; Bock, E.; Valois, F.W.; Waterbury, J.B.; Schlosser, U. Nitrospira marina gen. nov. sp. nov.: A chemo-lithotrophic nitrite-oxidizing bacterium. Arch. Microbiol. 1986, 144, 1-7. [CrossRef] 
27. Ge, S.; Wang, S.; Yang, X.; Qiu, S.; Li, B.; Peng, Y. Detection of nitrifiers and evaluation of partial nitrification for wastewater treatment: A review. Chemosphere 2015, 140, 85-98. [CrossRef]

28. Wett, B.; Nyhuis, G.; Takács, I.; Murthy, S. Development of Enhanced Deammonification Selector. Proc. Water Environ. Fed. 2010, 2010, 5917-5926. [CrossRef]

29. Liu, G.; Wang, J. Long-Term Low DO Enriches and Shifts Nitrifier Community in Activated Sludge. Environ. Sci. Technol. 2013, 47, 5109-5117. [CrossRef]

30. Isanta, E.; Reino, C.; Carrera, J.; Pérez, J. Stable partial nitritation for low-strength wastewater at low temperature in an aerobic granular reactor. Water Res. 2015, 80, 149-158. [CrossRef] [PubMed]

31. Ahn, J.H.; Kwan, T.; Chandran, K. Comparison of Partial and Full Nitrification Processes Applied for Treating High-Strength Nitrogen Wastewaters: Microbial Ecology through Nitrous Oxide Production. Environ. Sci. Technol. 2011, 45, 2734-2740. [CrossRef] [PubMed]

32. Liang, Y.; Li, D.; Zhang, X.; Zeng, H.; Yang, Z.; Cui, S.; Zhang, J. Stability and nitrite-oxidizing bacteria community structure in different high-rate CANON reactors. Bioresour. Technol. 2015, 175, 189-194. [CrossRef] [PubMed]

33. Pedrouso, A.; Del Río, V.; Morales, N.; Padín, J.R.V.; Campos, J.L.; Méndez, R.; Mosquera-Corral, A. Nitrite oxidizing bacteria suppression based on in-situ free nitrous acid production at mainstream conditions. Sep. Purif. Technol. 2017, 186, 55-62. [CrossRef]

34. Gilbert, E.M.; Agrawal, S.; Brunner, F.; Schwartz, T.; Horn, H.; Lackner, S. Response of DifferentNitrospiraSpecies To Anoxic Periods Depends on Operational DO. Environ. Sci. Technol. 2014, 48, 2934-2941. [CrossRef]

35. Kong, Q.; Zhang, J.; Ngo, H.H.; Ni, S.; Fu, R.; Guo, W.; Guo, N.; Tian, L. Nitrous oxide emission in an aerobic granulation se-quencing batch airlift reactor at ambient temperatures. Int. Biodeterior. Biodegrad. 2013, 85, 533-538. [CrossRef]

36. Fukushima, T.; Whang, L.-M.; Chiang, T.-Y.; Lin, Y.-H.; Chevalier, L.R.; Chen, M.-C.; Wu, Y.-J. Nitrifying bacterial community structures and their nitrification performance under sufficient and limited inorganic carbon conditions. Appl. Microbiol. Biotechnol. 2012, 97, 6513-6523. [CrossRef]

37. Huang, X.; Urata, K.; Wei, Q.; Yamashita, Y.; Hama, T.; Kawagoshi, Y. Fast start-up of partial nitritation as pre-treatment for anammox in membrane bioreactor. Biochem. Eng. J. 2016, 105, 371-378. [CrossRef]

38. Jin, P.; Li, B.; Mu, D.; Li, X.; Peng, Y. High-efficient nitrogen removal from municipal wastewater via two-stage nitritation/anammox process: Long-term stability assessment and mechanism analysis. Bioresour. Technol. 2019, 271, 150-158. [CrossRef]

39. Keerio, H.A.; Bae, W.; Park, J.; Kim, M. Substrate uptake, loss, and reserve in ammonia-oxidizing bacteria (AOB) under different substrate availabilities. Process Biochem. 2020, 91, 303-310. Available online: https://wwwcbio.sciencedirect.com/science/article/ pii/S135951132019.12.02315727 (accessed on 30 December 2019). [CrossRef]

40. Strous, M.; Heijnen, J.J.; Kuenen, J.G.; Jetten, M.S.M. The sequencing batch reactor as a powerful tool for the study of slowly growing anaerobic ammonium-oxidizing microorganisms. Appl. Microbiol. Biotechnol. 1998, 50, 589-596. [CrossRef]

41. Gilbert, E.M.; Agrawal, S.; Schwartz, T.; Horn, H.; Lackner, S. Comparing different reactor configurations for Partial Nitritation/Anammox at low temperatures. Water Res. 2015, 81, 92-100. [CrossRef]

42. Pereira, A.D.; Cabezas, A.; Etchebehere, C.; Chernicharo, C.A.D.L.; De Araújo, J.C. Microbial communities in anammox reactors: A review. Environ. Technol. Rev. 2017, 6, 74-93. [CrossRef]

43. Ye, L.; Li, D.; Zhang, J.; Zeng, H. Resuscitation of starved anaerobic ammonium oxidation sludge system: Impacts of repeated short-term starvation. Bioresour. Technol. 2018, 263, 458-466. [CrossRef]

44. Zaborowska, E.; Majtacz, J.; Drewnowski, J.; Sobotka, D.; Al-Hazmi, H.; Kowal, P.; Makinia, J. Improving the energy balance in wastewater treatment plants by optimization of aeration control and application of new technologies. In Water Supply Wastewater Disposal; Sobczuk, H., Kowalska, B., Eds.; Lublin University of Technology: Lublin, Poland, 2018; pp. 317-328.

45. Jubany, I.; Lafuente, J.; Baeza, J.A.; Carrera, J. Total and stable washout of nitrite oxidizing bacteria from a nitrifying continuous activated sludge system using automatic control based on Oxygen Uptake Rate measurements. Water Res. 2009, 43, $2761-2772$. [CrossRef] [PubMed]

46. Strous, M.; Kuenen, J.G.; Jetten, M.S.M. Key Physiology of Anaerobic Ammonium Oxidation. Appl. Environ. Microbiol. 1999, 65, 3248-3250. [CrossRef]

47. He, S.; Niu, Q.; Ma, H.; Zhang, Y.; Li, Y.-Y. The Treatment Performance and the Bacteria Preservation of Anammox: A Review. Water Air Soil Pollut. 2015, 226, 1-16. [CrossRef]

48. Rodriguez-Sanchez, A.; Purswani, J.; Lotti, T.; Maza-Marquez, P.; Van Loosdrecht, M.C.M.; Vahala, R.; Gonzalez-Martinez, A. Distribution and microbial community structure analysis of a single-stage partial nitritation/anammox granular sludge bioreactor operating at low temperature. Environ. Technol. 2016, 37, 2281-2291. [CrossRef] [PubMed]

49. Persson, F.; Sultana, R.; Suarez, M.; Hermansson, M.; Plaza, E.; Wilén, B.-M. Structure and composition of biofilm communities in a moving bed biofilm reactor for nitritation-anammox at low temperatures. Bioresour. Technol. 2014, 154, 267-273. [CrossRef] [PubMed]

50. Trojanowicz, K.; Plaza, E.; Trela, J. Pilot scale studies on nitritation-anammox process for mainstream wastewater at low temperature. Water Sci. Technol. 2015, 73, 761-768. [CrossRef]

51. Wang, X.; Qi, G.; Yan, Y.; Gao, D. Influence of temperature fluctuations on one-stage deammonification systems in northern cold region. Environ. Sci. Pollut. Res. 2018, 25, 18632-18641. [CrossRef] 
52. Lackner, S.; Welker, S.; Gilbert, E.M.; Horn, H. Influence of seasonal temperature fluctuations on two different partial nitritationanammox reactors treating mainstream municipal wastewater. Water Sci. Technol. 2015, 72, 1358-1363. [CrossRef] [PubMed]

53. Anthonisen, A.C.; Srinath, E.G.G.; Loehr, R.C.; Prakasam, T.B.S.; Srinath, E.G.G. Inhibition of nitrification and nitrous acid compounds. Water Environ. Pollut. Control Fed. 1976, 48, 835-852.

54. Metcalf, L.; Eddy, H.P.; Tchobanoglous, G. Wastewater Engineering: Treatment, Disposal, and Reuse; McGraw-Hill: New York, NY, USA, 1979; Volume 4.

55. Guo, J.; Peng, Y.; Huang, H.; Wang, S.; Ge, S.; Zhang, J.; Wang, Z. Short- and long-term effects of temperature on partial nitrification in a sequencing batch reactor treating domestic wastewater. J. Hazard. Mater. 2010, 179, 471-479. [CrossRef] [PubMed]

56. Gabarró, J.; Ganigué, R.; Gich, F.; Ruscalleda, M.; Balaguer, M.; Colprim, J. Effect of temperature on AOB activity of a partial nitritation SBR treating landfill leachate with extremely high nitrogen concentration. Bioresour. Technol. 2012, 126, 283-289. [CrossRef]

57. Hellinga, C.; Schellen, A.; Mulder, J.; Vanloosdrecht, M.; Heijnen, J. The sharon process: An innovative method for nitrogen removal from ammonium-rich waste water. Water Sci. Technol. 1998, 37, 135-142. [CrossRef]

58. Lotti, T.; Kleerebezem, R.; Hu, Z.; Kartal, B.; Jetten, M.; Van Loosdrecht, M. Simultaneous partial nitritation and anammox at low temperature with granular sludge. Water Res. 2014, 66, 111-121. [CrossRef]

59. Gilbert, E.M.; Agrawal, S.; Karst, S.M.; Horn, H.; Nielsen, P.H.; Lackner, S. Low temperature partial nitritation/anammox in a moving bed biofilm reactor treating low strength wastewater. Environ Sci. Technol. 2014, 48, 8784-8792. [CrossRef]

60. Zekker, I.; Rikmann, E.; Mandel, A.; Kroon, K.; Seiman, A.; Mihkelson, J.; Tenno, T.; Tenno, T. Step-wise temperature decreasing cultivates a biofilm with high nitrogen removal rates at $9{ }^{\circ} \mathrm{C}$ in short-term anammox biofilm tests. Environ. Technol. 2016, 37, 1933-1946. [CrossRef]

61. Soliman, M.; Eldyasti, A. Development of partial nitrification as a first step of nitrite shunt process in a Sequential Batch Reactor (SBR) using Ammonium Oxidizing Bacteria (AOB) controlled by mixing regime. Bioresour. Technol. 2016, 221, 85-95. [CrossRef]

62. Li, X.; Sun, S.; Badgley, B.D.; Sung, S.; Zhang, H.; He, Z. Nitrogen removal by granular nitritation-anammox in an upflow membrane-aerated biofilm reactor. Water Res. 2016, 94, 23-31. [CrossRef]

63. Wang, H.; Xu, G.; Qiu, Z.; Zhou, Y.; Liu, Y. NOB suppression in pilot-scale mainstream nitritation-denitritation system coupled with MBR for municipal wastewater treatment. Chemosphere 2019, 216, 633-639. [CrossRef]

64. Third, K.A.; Paxman, J.; Schmid, M.; Strous, M.; Jetten, M.S.M.; Cord-Ruwisch, R. Enrichment of anammox from ac-tivated sludge and its application in the CANON process. Microb. Ecol. 2005, 49, 236-244. [CrossRef]

65. Corbalá-Robles, L.; Picioreanu, C.; Van Loosdrecht, M.C.; Pérez, J. Analysing the effects of the aeration pattern and residual ammonium concentration in a partial nitritation-anammox process. Environ. Technol. 2015, 37, 694-702. [CrossRef] [PubMed]

66. Sobotka, D.; Czerwionka, K.; Makinia, J. The effects of different aeration modes on ammonia removal from sludge digester liquors in the nitritation-anammox process. Water Sci. Technol. 2015, 71, 986-995. [CrossRef] [PubMed]

67. Sun, Y.; Guan, Y.; Pan, M.; Zhan, X.; Hu, Z.; Wu, G. Enhanced biological nitrogen removal and N2O emission characteristics of the intermittent aeration activated sludge process. Rev. Environ. Sci. Biotechnol. 2017, 6, 761-780. [CrossRef]

68. Miao, Y.; Zhang, L.; Yang, Y.; Peng, Y.; Li, B.; Wang, S.; Zhang, Q. Start-up of single-stage partial nitrification-anammox process treating low-strength swage and its restoration from nitrate accumulation. Bioresour. Technol. 2016, 218, 771-779. [CrossRef] [PubMed]

69. Pan, M.; Henry, L.G.; Liu, R.; Huang, X.; Zhan, X. Nitrogen removal from slaughterhouse wastewater through par-tial nitrification followed by denitrification in intermittently aerated sequencing batch reactors at $11^{\circ} \mathrm{C}$. Environ. Technol. 2014, 35, 470-477. [CrossRef] [PubMed]

70. Miao, Y.; Zhang, L.; Li, B.; Zhang, Q.; Wang, S.; Peng, Y. Enhancing ammonium oxidizing bacteria activity was key to single-stage partial nitrification-anammox system treating low-strength sewage under intermittent aeration condition. Bioresour. Technol. 2017, 231, 36-44. [CrossRef]

71. Ma, B.; Bao, P.; Wei, Y.; Zhu, G.; Yuan, Z.; Peng, Y. Suppressing Nitrite-oxidizing Bacteria Growth to Achieve Nitrogen Removal from Domestic Wastewater via Anammox Using Intermittent Aeration with Low Dissolved Oxygen. Sci. Rep. 2015, 5, 13048. [CrossRef]

72. Miao, Y.; Peng, Y.; Zhang, L.; Li, B.; Li, X.; Wu, L.; Wang, S. Partial nitrification-anammox (PNA) treating sewage with intermittent aeration mode: Effect of influent $\mathrm{C} / \mathrm{N}$ ratios. Chem. Eng. J. 2018, 334, 664-672. [CrossRef]

73. Su, Q.; Mark, J.M.; Domingo-Félez, C.; Kiil, A.S.; Thamdrup, B.; Jensen, M.M.; Smets, B.F. Low nitrous oxide production through nitrifier-denitrification in intermittent-feed high-rate nitritation reactors. Water Res. 2017, 123, 429-438. [CrossRef]

74. Blum, J.-M.; Jensen, M.M.; Smets, B.F. Nitrous oxide production in intermittently aerated Partial Nitritation-Anammox reactor: Oxic N2O production dominates and relates with ammonia removal rate. Chem. Eng. J. 2018, 335, 458-466. [CrossRef]

75. Yang, J.; Trela, J.; Zubrowska-Sudol, M.; Plaza, E. Intermittent aeration in one-stage partial nitritation/anammox process. Ecol. Eng. 2015, 75, 413-420. [CrossRef]

76. Bao, P.; Wang, S.; Ma, B.; Zhang, Q.; Peng, Y. Achieving partial nitrification by inhibiting the activity of Nitrospira-like bacteria under high-DO conditions in an intermittent aeration reactor. J. Environ. Sci. 2017, 56, 71-78. [CrossRef]

77. Zhang, C.; Zhang, S.; Zhang, L. Effects of constant $\mathrm{pH}$ and unsteady $\mathrm{pH}$ at different free ammonia concentra-tions on shortcut nitrification for landfill leachate treatment. Appl. Microbiol. Biotechnol. 2015, 99, 3707-3713. [CrossRef] 
78. Wei, D.; Du, B.; Xue, X.; Dai, P.; Zhang, J. Analysis of factors affecting the performance of partial nitrification in a sequencing batch reactor. Appl. Microbiol. Biotechnol. 2013, 98, 1863-1870. [CrossRef] [PubMed]

79. Daverey, A.; Hung, N.-T.; Dutta, K.; Lin, J.-G. Ambient temperature SNAD process treating anaerobic digester liquor of swine wastewater. Bioresour. Technol. 2013, 141, 191-198. [CrossRef] [PubMed]

80. Tao, W.; He, Y.; Wang, Z.; Smith, R.; Shayya, W.; Pei, Y. Effects of pH and temperature on coupling nitritation and anammox in biofilters treating dairy wastewater. Ecol. Eng. 2012, 47, 76-82. [CrossRef]

81. Tang, H.L.; Chen, H. Nitrification at full-scale municipal wastewater treatment plants: Evaluation of inhibition and bioaugmentation of nitrifiers. Bioresour. Technol. 2015, 190, 76-81. [CrossRef] [PubMed]

82. Taylor, P.; Li, P.; Wang, S.; Peng, Y.; Liu, Y.; He, J. The synergistic effects of dissolved oxygen and pH on $\mathrm{N}_{2} \mathrm{O}$ pro-duction in biological domestic wastewater treatment under nitrifying conditions. Environ. Technol. 2015, 36, 37-41.

83. Kinh, C.T.; Ahn, J.; Suenaga, T.; Sittivorakulpong, N.; Noophan, P.; Hori, T.; Riya, S.; Hosomi, M.; Terada, A. Free nitrous acid and $\mathrm{pH}$ determine the predominant ammonia-oxidizing bacteria and amount of N2O in a partial nitrifying reactor. Appl. Microbiol. Biotechnol. 2016, 101, 1673-1683. [CrossRef]

84. Rathnayake, R.M.; Oshiki, M.; Ishii, S.; Segawa, T.; Satoh, H.; Okabe, S. Effects of dissolved oxygen and pH on nitrous oxide production rates in autotrophic partial nitrification granules. Bioresour. Technol. 2015, 197, 15-22. [CrossRef] [PubMed]

85. Su, Q.; Domingo-Félez, C.; Zhang, Z.; Blum, J.-M.; Jensen, M.M.; Smets, B.F. The effect of $\mathrm{pH}$ on $\mathrm{N}_{2} \mathrm{O}$ production in intermittentlyfed nitritation reactors. Water Res. 2019, 156, 223-231. [CrossRef] [PubMed]

86. Massara, T.M.; Malamis, S.; Guisasola, A.; Baeza, J.A.; Noutsopoulos, C.; Katsou, E. A review on nitrous oxide $\left(\mathrm{N}_{2} \mathrm{O}\right)$ emissions during biological nutrient removal from municipal wastewater and sludge reject water. Sci. Total Environ. 2017, 596-597, 106-123. [CrossRef] [PubMed]

87. Jaroszynski, L.; Cicek, N.; Sparling, R.; Oleszkiewicz, J. Impact of free ammonia on anammox rates (anoxic ammonium oxidation) in a moving bed biofilm reactor. Chemosphere 2012, 88, 188-195. [CrossRef]

88. Hultman, B. Biological Nitrogen Reduction Studied as a General Microbiological Engineering Process. In Environmental Engineering; Springer: New York, NY, USA, 1973; pp. 339-350. [CrossRef]

89. Antoniou, P.; Hamilton, J.; Koopman, B.; Jain, R.; Holloway, B.; Lyberatos, G.; Svoronos, S. Effect of temperature and ph on the effective maximum specific growth rate of nitrifying bacteria. Water Res. 1990, 24, 97-101. [CrossRef]

90. Angelidaki, I.; Ellegaard, L.; Ahring, B.K. A mathematical model for dynamic simulation of anaerobic digestion of complex substrates: Focusing on ammonia inhibition. Biotechnol. Bioeng. 1993, 42, 159-166. [CrossRef] [PubMed]

91. Zhou, Y.; Oehmen, A.; Lim, M.; Vadivelu, V.; Ng, W.J. The role of nitrite and free nitrous acid (FNA) in wastewater treatment plants. Water Res. 2011, 45, 4672-4682. [CrossRef]

92. Wei, D.; Xue, X.; Yan, L.; Sun, M.; Zhang, G.; Shi, L.; Du, B. Effect of influent ammonium concentration on the shift of full nitritation to partial nitrification in a sequencing batch reactor at ambient temperature. Chem. Eng. J. 2014, 235, 19-26. [CrossRef]

93. Im, J.; Jung, J.; Bae, H.; Kim, D.; Gil, K. Correlation between nitrite accumulation and the concentration of AOB in a nitritation reactor. Environ. Earth Sci. 2014, 72, 289-297. [CrossRef]

94. Sun, H.; Peng, Y.; Wang, S.; Ma, J. Achieving nitritation at low temperatures using free ammonia inhibition on Nitrobacter and real-time control in an SBR treating landfill leachate. J. Environ. Sci. 2015, 30, 157-163. [CrossRef]

95. Hou, B.; Han, H.; Jia, S.; Zhuang, H.; Zhao, Q.; Xu, P. Effect of alkalinity on nitrite accumulation in treatment of coal chemical industry wastewater using moving bed biofilm reactor. J. Environ. Sci. 2014, 26, 1014-1022. [CrossRef]

96. Qian, W.; Peng, Y.; Li, X.; Zhang, Q.; Ma, B. The inhibitory effects of free ammonia on ammonia oxidizing bacteria and nitrite oxidizing bacteria under anaerobic condition. Bioresour. Technol. 2017, 243, 1247-1250. [CrossRef]

97. Wang, Q. A Roadmap for Achieving Energy-Positive Sewage Treatment Based on Sludge Treatment Using Free Ammonia. ACS Sustain. Chem. Eng. 2017, 5, 9630-9633. [CrossRef]

98. Wang, Q.; Ye, L.; Jiang, G.; Hu, S.; Yuan, Z. Side-stream sludge treatment using free nitrous acid selectively eliminates nitrite oxidizing bacteria and achieves the nitrite pathway. Water Res. 2014, 55, 245-255. [CrossRef]

99. Zeng, D.; Miao, J.; Wu, G.; Zhan, X. Nitrogen removal, microbial community and electron transport in an integrated nitrification and denitrification system for ammonium-rich wastewater treatment. Int. Biodeterior. Biodegrad. 2018, 133, 202-209. [CrossRef]

100. Laloo, A.E.; Wei, J.; Wang, D.; Narayanasamy, S.; Vanwonterghem, I.; Waite, D.; Steen, J.; Kaysen, A.; Heintz-Buschart, A.; Wang, Q.; et al. Mechanisms of Persistence of the Ammonia-Oxidizing Bacteria Nitrosomonas to the Biocide Free Nitrous Acid. Environ. Sci. Technol. 2018, 52, 5386-5397. [CrossRef] [PubMed]

101. Wang, Q.; Hao, X.; Yuan, Z. Towards energy positive wastewater treatment by sludge treatment using free nitrous acid. Chemosphere 2016, 144, 1869-1873. [CrossRef]

102. Pei, L.-Y.; Wan, Q.; Wang, Z.-F.; Wang, B.-B.; Zhang, X.-Y.; Hou, Y.-P. Effect of long-term bioaugmentation on nitrogen removal and microbial ecology for an A2O pilot-scale plant operated in low SRT. Desalin. Water Treat. 2014, 55, 1567-1574. [CrossRef]

103. Cao, Y.; Van Loosdrecht, M.C.M.; Daigger, G.T. Mainstream partial nitritation-anammox in municipal wastewater treatment: Status, bottlenecks, and further studies. Appl. Microbiol. Biotechnol. 2017, 101, 1365-1383. [CrossRef] [PubMed]

104. Stinson, B.; Murthy, S.; Bott, C.; Wett, B.; Al-Omari, A.; Bowden, G.; Mokhyerie, Y.; De Clippeleir, H. Roadmap toward energy neutrality \& chemical optimization at enhanced nutrient removal facilities. In Proceedings of the WEF/IWA Nutrient Removal and Recovery 2013: Trends in Resource Recovery and Use, Vancouver, BC, Canada, 28-31 July 2013; pp. 702-731. 
105. Figueroa, M.; Vázquez-Padín, J.R.; Mosquera-Corral, A.; Campos, J.L.; Méndez, R. Is the CANON reactor an alternative for nitrogen removal from pre-treated swine slurry? Biochem. Eng. J. 2012, 65, 23-29. [CrossRef]

106. Liang, Y.-C.; Daverey, A.; Huang, Y.-T.; Sung, S.; Lin, J.-G. Treatment of semiconductor wastewater using single-stage partial nitrification and anammox in a pilot-scale reactor. J. Taiwan Inst. Chem. Eng. 2016, 63, 236-242. [CrossRef]

107. Shourjeh, M.S.; Kowal, P.; Drewnowski, J.; Szelag, B.; Szaja, A.; Łagód, G. Mutual Interaction between Temperature and DO Set Point on AOB and NOB Activity during Shortcut Nitrification in a Sequencing Batch Reactor in Terms of Energy Consumption Optimization. Energies 2020, 13, 5808. [CrossRef]

108. Bott, C.B.; Parker, D.S. WEF/WERF Study Quantifying Nutrient Removal Technology Performance; Water Environment Research Foundation: Alexandria, VA, USA, 2011; Volume 10. [CrossRef]

109. Morales, N.; Val del Río, Á.; Vázquez-Padín, J.R.; Méndez, R.; Campos, J.L.; Mosquera-Corral, A. The granular bio-mass properties and the acclimation period affect the partial nitritation/anammox process stability at a low temperature and ammonium concentration. Process Biochem. 2016, 51, 2134-2142. [CrossRef]

110. Regmi, P.; Miller, M.W.; Holgate, B.; Bunce, R.; Park, H.; Chandran, K.; Wett, B.; Murthy, S.; Bott, C.B. Control of aeration, aerobic SRT and COD input for mainstream nitritation/denitritation. Water Res. 2014, 57, 162-171. [CrossRef]

111. Wett, B. Development and implementation of a robust deammonification process. Water Sci. Technol. 2007, 56, 81-88. [CrossRef]

112. Salmistraro, M.; Fernández, I.; Dosta, J.; Plaza, E.; Mata, J. Mainstream Deammonification: Preliminary Experi-ence Employing Granular AOB-Enriched Biomass at Low DO Values. Water Air Soil Pollut. 2017, 228, 178. [CrossRef]

113. Al-Hazmi, H.; Grubba, D.; Majtacz, J.; Kowal, P.; Makinia, J. Evaluation of Partial Nitritation/Anammox (PN/A) Process Performance and Microorganisms Community Composition under Different C/N Ratio. Water 2019, 11, 2270. [CrossRef]

114. De Prá, M.C.; Kunz, A.; Bortoli, M.; Scussiato, L.A.; Coldebella, A.; Vanotti, M.; Soares, H.M. Kinetic models for nitrogen in-hibition in ANAMMOX and nitrification process on deammonification system at room temperature. Bioresour. Technol. 2016, 202, 33-41. [CrossRef]

115. Mattei, M.; Frunzo, L.; D’Acunto, B.; Esposito, G.; Pirozzi, F. Modelling microbial population dynamics in multispecies biofilms including Anammox bacteria. Ecol. Model. 2015, 304, 44-58. [CrossRef]

116. Gu, J.; Yang, Q.; Liu, Y. Mainstream anammox in a novel A-2B process for energy-efficient municipal wastewater treatment with minimized sludge production. Water Res. 2018, 138, 1-6. [CrossRef] [PubMed]

117. Tanyolaç, D.; Salih, B.; Tanyolaç, A. Inhibition kinetics of a commercial mixed culture by ammonium sulfate. Biochem. Eng. J. 2001, 7, 177-182. [CrossRef]

118. Simsek, H.; Kasi, M.; Ohm, J.-B.; Murthy, S.; Khan, E. Impact of solids retention time on dissolved organic nitrogen and its biodegradability in treated wastewater. Water Res. 2016, 92, 44-51. [CrossRef]

119. Edwards, V.H. The influence of high substrate concentrations on microbial kinetics. Biotechnol. Bioeng. 1970, 12, 679-712. [CrossRef] [PubMed]

120. Baek, S.H.; Kim, H.J. Mathematical model for simultaneous nitrification and denitrification (SND) in mem-brane bioreactor (MBR) under Low Dissolved Oxygen (DO) concentrations. Biotechnol. Bioprocess Eng. 2013, 18, 104-110. [CrossRef]

121. Bournazou, M.C.; Hooshiar, K.; Arellano-Garcia, H.; Wozny, G.; Lyberatos, G. Model based optimization of the intermittent aeration profile for SBRs under partial nitrification. Water Res. 2013, 47, 3399-3410. [CrossRef] [PubMed]

122. Ni, B.J.; Peng, L.; Law, Y.; Guo, J.; Yuan, Z. Modeling of nitrous oxide production by autotrophic ammo-nia-oxidizing bacteria with multiple production pathways. Environ. Sci. Technol. 2014, 48, 3916-3924. [CrossRef]

123. Massara, T.M.; Solís, B.; Guisasola, A.; Katsou, E.; Baeza, J.A. Development of an ASM2d-N2O model to describe nitrous oxide emissions in municipal WWTPs under dynamic conditions. Chem. Eng. J. 2018, 335, 185-196. [CrossRef]

124. Drewnowski, J.; Wisniewski, K.; Szaja, A.; Lagod, G.; Vega, C. The process generation of WWTP models for opti-mization of activated sludge systems. In Environmental Engineering $V$; CRC Press: London, UK, 2017; pp. 187-195.

125. Zheng, M.; Wu, S.; Zuo, Z.; Wang, Z.; Qiu, Y.; Liu, Y.-C.; Huang, X.; Yuan, Z. Predictions of the Influent and Operational Conditions for Partial Nitritation with a Model Incorporating pH Dynamics. Environ. Sci. Technol. 2018, 52, 6457-6465. [CrossRef]

126. Drewnowski, J.; Makinia, J.; Kopec, L.; Fernandez-Morales, F.-J. Modelization of Nutrient Removal Processes at a Large WWTP Using a Modified ASM2d Model. Int. J. Environ. Res. Public Health 2018, 15, 2817. [CrossRef]

127. Pérez, J.; Lotti, T.; Kleerebezem, R.; Picioreanu, C.; Van Loosdrecht, M.C. Outcompeting nitrite-oxidizing bacteria in single-stage nitrogen removal in sewage treatment plants: A model-based study. Water Res. 2014, 66, 208-218. [CrossRef]

128. Wu, J.; He, C.; Van Loosdrecht, M.C.; Pérez, J. Selection of ammonium oxidizing bacteria (AOB) over nitrite oxidizing bacteria (NOB) based on conversion rates. Chem. Eng. J. 2016, 304, 953-961. [CrossRef]

129. Al-Omari, A.; Wett, B.; Nopens, I.; De Clippeleir, H.; Han, M.; Regmi, P.; Bott, C.; Murthy, S. Model-based evaluation of mecha-nisms and benefits of mainstream shortcut nitrogen removal processes. Water Sci. Technol. 2015, 71, 840-847. [CrossRef] [PubMed]

130. Qi, W.; He, S.; Zhang, Y.; Xu, J.; Yang, X.J.; Li, Y. Optimisation for Enriching Ammonium Oxidizing Bacteria in Membrane Partial Nitrification Reactor: Mathematical Simulation. Water Sustain. 2016, 6, 125-137.

131. Smets, B.F. Suppression of Nitrite-Oxidizing Bacteria in Intermittently 2 Membrane-Aerated Biofilms: A Model-Based Explanation. Environ. Sci. Technol. 2017, 51, 6146-6155.

132. Cui, F.; Park, S.; Mo, K.; Lee, W.; Lee, H.; Kim, M. Experimentation and Mathematical Models for Partial Nitrifica-tion in Aerobic Granular Sludge Process. Civ. Eng. 2017, 21, 127-133. 
133. Peng, L.; Liu, Y.; Ni, B.-J. Nitrous oxide production in completely autotrophic nitrogen removal biofilm process: A simulation study. Chem. Eng. J. 2016, 287, 217-224. [CrossRef]

134. Mannina, G.; Cosenza, A.; Viviani, G.; Ekama, G.A. Sensitivity and uncertainty analysis of an integrated ASM2d MBR model for wastewater treatment. Chem. Eng. J. 2018, 351, 579-588. [CrossRef]

135. Ma, B.; Wang, S.; Zhang, S.; Li, X.; Bao, P.; Peng, Y. Achieving nitritation and phosphorus removal in a continuous-flow anaerobic/oxic reactor through bio-augmentation. Bioresour. Technol. 2013, 139, 375-378. [CrossRef]

136. Zheng, Z.; Li, J.; Ma, J.; Du, J.; Bian, W.; Li, Y.; Zhang, Y.; Zhao, B. Nitrogen removal via simultaneous partial nitrification, anam-mox and denitrification (SNAD) process under high DO condition. Biodegradation 2016, 27, 195-208. [CrossRef]

137. Laureni, M.; Weissbrodt, D.G.; Villez, K.; Robin, O.; de Jonge, N.; Rosenthal, A.; Wells, G.; Nielsen, J.L.; Morgenroth, E.; Joss, A. Biomass segregation between biofilm and flocs improves the control of nitrite-oxidizing bacteria in mainstream partial nitritation and anammox processes. Water Res. 2019, 154, 104-116. [CrossRef]

138. Li, J.; Zhang, L.; Peng, Y.; Yang, S.; Wang, X.; Li, X.; Zhang, Q. NOB suppression in partial nitritation-anammox (PNA) process by discharging aged flocs: Performance and microbial community dynamics. Chemosphere 2019, 227, 26-33. [CrossRef]

139. Wang, J.; Qian, F.; Liu, X.; Liu, W.; Wang, S.; Shen, Y. Cultivation and characteristics of partial nitrification granular sludge in a sequencing batch reactor inoculated with heterotrophic granules. Appl. Microbiol. Biotechnol. 2016, 100, 9381-9391. [CrossRef]

140. Reino, C.; Suárez-Ojeda, M.E.; Pérez, J.; Carrera, J. Kinetic and microbiological characterization of aerobic granules performing partial nitritation of a low-strength wastewater at $10^{\circ} \mathrm{C}$. Water Res. 2016, 101, 147-156. [CrossRef] [PubMed]

141. Zhang, X.; Liang, Y.; Ma, Y.; Du, J.; Pang, L.; Zhang, H. Ammonia removal and microbial characteristics of partial nitrification in biofilm and activated sludge treating low strength sewage at low temperature. Ecol. Eng. 2016, 93, 104-111. [CrossRef]

142. Cao, Y.; Zhang, C.; Rong, H.; Zheng, G.; Zhao, L. The effect of dissolved oxygen concentration (DO) on oxygen diffusion and bacterial community structure in moving bed sequencing batch reactor (MBSBR). Water Res. 2017, 108, 86-94. [CrossRef]

143. Cui, H.; Zhang, L.; Zhang, Q.; Li, X.; Peng, Y. Stable partial nitrification of domestic sewage achieved through activated sludge on exposure to nitrite. Bioresour. Technol. 2019, 278, 435-439. [CrossRef]

144. Chen, R.; Ji, J.; Chen, Y.; Takemura, Y.; Liu, Y.; Kubota, K.; Ma, H.; Li, Y.-Y. Successful operation performance and syntrophic microgranule in partial nitritation and anammox reactor treating low-strength ammonia wastewater. Water Res. 2019, 155, $288-299$. [CrossRef] [PubMed] 